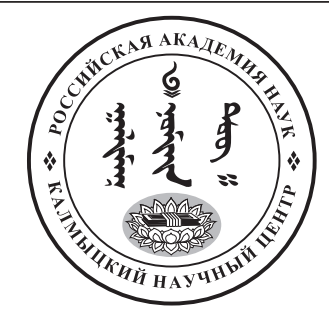

Published in the Russian Federation

Oriental Studies (Previous Name: Bulletin of the Kalmyk Institute

for Humanities of the Russian Academy of Sciences)

Has been issued as a journal since 2008

ISSN: 2619-0990; E-ISSN: 2619-1008

Vol. 13, Is. 3, pp. 661-687, 2020

DOI: $10.22162 / 2619-0990-2020-49-3-661-687$

Journal homepage: https://kigiran.elpub.ru

УДК 39

DOI: 10.22162/2619-0990-2020-49-3-661-687

\title{
Почитание Большой Медведицы в среде ойратов и калмыков: древнейшие представления и буддийские напластования. Часть 2
}

\author{
Эльза Петровна Бакаева
}

${ }^{1}$ Калмыцкий научный центр РАН (д. 8, ул. И. К. Илишкина, 358000 Элиста, Российская Федерация) доктор исторических наук, заместитель директора, ведущий научный сотрудник

iD 0000-0002-5188-1202. E-mail: bakaevaep@kigiran.com

(C) КалмНЦ РАН, 2020

(С) Бакаева Э. П., 2020

Аннотация. Введение. Большая Медведица - самое почитаемое созвездие у монгольских народов. Цель статьи - провести анализ представлений, связанных с этим созвездием, по данным фольклорных и полевых материалов, выделить основные мифологические характеристики и осветить проблему разновременных напластований в верованиях о созвездии Большая Медведица в среде калмыков и ойратов (западных монголов). В соответствии с целью поставлены две задачи: провести анализ основных сюжетов о происхождении Большой Медведицы, известных среди калмыков и ойратов, в сопоставлении с сюжетами, известными у других монгольских народов; рассмотреть представления о Большой Медведице в сопоставлении с некоторыми календарными обрядами и мифологическими образами, почитаемыми в культуре калмыков и ойратов, а также осветить современные обряды, направленные к созвездию. Maтериалы. К анализу привлекаются фольклорные материалы и сведения этнографического характера. Результаты. В первой части статьи выявлены основные варианты мифологических текстов о Большой Медведице (монг. Долоон бурхан, Долоон өвгөн, калм. Долан бурхн, Долан одн) у калмыков и ойратов в сопоставлении с мифами других монгольских народов. Показано, что основные варианты мифа о происхождении Большой Медведицы связаны с представлениями о семи персонажах-мужчинах (братьях, названных братьях, ворах) или о человеко-быке, но происхождение терминов может указывать на возможную связь темы происхождения созвездия также с известным архаическим сюжетом о смене дня и ночи как отражении погони за оленихой и солярной темой. Во второй части статьи представления о Большой Медведице проанализированы в сопоставлении с некоторыми календарными обрядами и мифологическими образами, почитаемыми в культуре калмыков и ойратов. Показано, что Большую Медведицу ойраты иногда именовали Долоон марал 'Семь маралов', что позволяет привлечь к сопоставительному анализу легенды о погоне небесного охотника за маралухами. В устной традиции ойратов зафиксированы представления о том, что персонажи созвездия Большая Медведица, как и небесный охотник Хухэдэй Мэргэн (преследовавший трех маралух, которые обычно счи- 
таются превратившимися в три звезды Пояса Ориона и давшими название созвездию Орион - монг. Гурван марал, калм. Һурвн марл 'Три маралухи'), могут считаться хозяевами двух привязанных к «золотому колу» (т. е. Полярной звезде) коней, в качестве которых предстают в мифах две звезды Малой Медведицы. Большую Медведицу ойраты и калмыки почитают как связанную с потеплением на земле, а также покровительствующую детям, отпускающую грехи и защищающую отары от волков и способствующую увеличению численности скота, - эти же функции характерны и для образа божества Цаһан аав, которого ойраты почитают как хозяина Алтая, калмыки - как покровителя народа и в одной из его форм как Хозяина года Жилин эзн. В статье также проанализированы современные буддийские представления о почитании созвездия Большая Медведица у монгольских народов.

Ключевые слова: Большая Медведица, монгольские народы, ойраты, калмыки, мифы, верования, архаический календарь, обряды

Благодарность. Исследование выполнено при финансовой поддержке гранта в форме субсидии из федерального бюджета, выделяемой для государственной поддержки научных исследований, проводимых под руководством ведущего ученого (проект «От палеогенетики до культурной антропологии: комплексное интердисциплинарное исследование традиций народов трансграничных регионов: миграции, межкультурное взаимодействие и картина мира»).

Для цитирования: Бакаева Э. П. Почитание Большой Медведицы в среде ойратов и калмыков: древнейшие представления и буддийские напластования. Часть 2 // Oriental Studies. 2020. Т. 13. № 3. C. 661-687. DOI: 10.22162/2619-0990-2020-49-3-661-687

UDC 39

DOI: $10.22162 / 2619-0990-2020-49-3-661-687$

\title{
Veneration of Ursa Major among the Oirats and Kalmyks: Ancient Beliefs and Later Buddhist Additions. Part 2
}

\author{
Elza P. Bakaeva ${ }^{1}$
}

${ }^{1}$ Kalmyk Scientific Center of the RAS (8, Ilishkin St., Elista 358000, Russian Federation).

Dr. Sc. (History), Deputy Director, Leading Research Associate

iD 0000-0002-5188-1202. E-mail: bakaevaep@kigiran.com

\author{
(C) KalmSC RAS, 2020
}

(C) Bakaeva E. P., 2020

\begin{abstract}
Introduction. Ursa Major is the constellation most venerated by Mongolic peoples. Goals. The article seeks to examine related beliefs traced in folklore and collected field data, reveal key mythological characteristics, and cast light upon diachronous layers in the beliefs of Kalmyks and Oirats (Western Mongols). So, the work aims at analyzing basic Kalmyk and Oirat folklore plots dealing with origins of the Great Bear in comparison to those of other Mongolic cultures; and at examining the concept of Ursa Major against the background of some calendar rites and revered mythological images with due regard of contemporary ceremonies addressed to the constellation. Materials. The paper analyzes folklore and ethnographic materials. Results. Part 1 of the article identifies main variants of mythological texts about Ursa Major (Mong. Долоон бурхан, Долоон өвгөн, Kalm. Долан бурхн, Долан одн) existing in Kalmyk and Oirat discourses, comparing the latter to myths of other Mongolic populations. It shows that basically the myths narrate about seven male characters (siblings, sworn brothers, or thieves) or an ox-man, though etymology of terms may tie the constellation (its emergence) to the archaic plot of day and night alternation as a chase of shedeer, and the solar theme at large. Part 2 further analyzes Ursa Major-related beliefs and compares the latter to some calendar rites and mythological images revered in Kalmyk and Oirat culture. The paper informs that the constellation was sometimes referred to by the Oirats as 'Seven Maral Deer' (Oir. Долоон марал), which implies our analysis may extend to the legend of how the heavenly hunter pursued a flock of she-deer. The Oirat oral tradition believes that both the characters of Ursa
\end{abstract}


Major stories and Khukhedei Mergen the Hunter (whose chase made three she-deer turn into the three stars of Orion's Belt therefore referred to by the Mongols as 'Three She-Deer', Mong. Гурван марал, Kalm. Һурвн марл) саn be considered masters of the two horses tied to the 'Golden Pole' (i.e. Pole Star) - two stars of Ursa Minor. Oirats and Kalmyks also associate Ursa Major with thawing weather, protection of children, livestock (from wolves), and increase of its numbers, remission of sins - similar functions attributed to the White Old Man (Kalm. Цаһан аав) revered by the Oirats as the Lord of the Altai, while Kalmyks tend to view him as a protector deity of the nation, one of his manifestations being that of the Lord of the Year (Kalm. Жилин эзн). The article also analyzes contemporary Buddhist rites dealing with Ursa Major among Mongolic populations.

Keywords: Ursa Major, Mongolic peoples, Oirats, Kalmyks, myths, beliefs, archaic calendar, rites Acknowledgements. The reported study was funded by government grant in the form of federal budget subsidy aimed to support scientific research directed by the Leading Scientist - project name 'From Paleogenetics to Cultural Anthropology: Comprehensive Interdisciplinary Research of Peoples and Traditions of Cross-Border Regions - Migrations, Cross-Cultural Interactions and Worldviews'. For citation: Bakaeva E. P. Veneration of Ursa Major among the Oirats and Kalmyks: Ancient Beliefs and Later Buddhist Additions. Part 2. Oriental Studies. 2020. Vol. 13(3):661-687. (In Russ.). DOI: 10.22162/2619-0990-2020-49-3-661-687

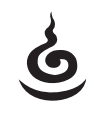

\section{Введение}

Большая Медведица - ясно видимое на небе на протяжении практически всего года созвездие - являлась объектом поклонения монгольских народов в древности и почитается в их среде до настоящего времени. Представления о созвездии на протяжении истории этих народов претерпевали трансформации, определенные как изменениями в обществе и развитием знаний, так и культурными влияниями.

Цель статьи - провести анализ представлений, связанных с этим созвездием, по данным полевых материалов и фольклоpa, выделить основные мифологические характеристики и осветить проблему разновременных напластований в верованиях о созвездии Большая Медведища в среде калмыков и ойратов (западных монголов). Целью определены две задачи, первая из которых - проведение анализа основных сюжетов о происхождении Большой Медведицы, известных среди калмыков и ойратов, в сопоставлении с сюжетами, известными у других монгольских народов - решалась в первой части статьи [Бакаева 2020]. В настоящей публикации, представляющей собой вторую часть статьи, ставится задача исследования других представлений о Большой Медведице в сопоставлении с некоторыми календарными обрядами и мифологическими образами, почитаемыми в культуре калмыков и ойратов, а также освещения буддийских представлений о созвез- дии, бытующих в среде монголов и ойратов в настоящее время.

Как показано в первой части статьи, большинство вариантов мифологических сюжетов монгольских народов о происхождении Большой Медведицы, собранных известным фольклористом Д. Цэрэнсодномом, посвящено семи персонажам, семи братьям, обладающим необычными способностями и вступающим в соревнования либо поединки и в завершение превращающимся в созвездие; в одном ойратском тексте семь персонажей совершают кражу браслета у ханши, но созвездие представляется не как антропоморфные персонажи, а как браслет [Цэрэнсодном 1989]; зафиксированы ученым и сюжеты о превращении в созвездие семи частей тела мифического существа человеко-быка, поражающего темного персонажа в виде быка (солярный по семантике сюжет о борьбе светлого и темного начал) и уничтоженного соратницей последнего, расколовшей тело человеко-быка на семь частей. Два основных варианта калмыцких текстов связаны с зафиксированными у других народов, но сюжет о семи мужских персонажах отличается тем, что они являются ворами (разбойниками), осуществившими важное действие - кражу одной звезды у созвездия Плеяд (Мичид), уменьшившую холодящую силу Плеяд [Семь звезд 2004: 44-47; Мифы, легенды 2017: 44-51]; «семь воров или разбойников, превращающихся в звезды, - редкая форма персонифика- 
ции звезд Большой Медведицы, известная у тюркских народов и у басков [Березкин 2017: 27]» [Мифы, легенды 2017: 291].

Второй вариант калмыцкого мифа о превращении в семь звезд частей тела человеко-быка, которое разрывается от удара противника, восходит, как и монгольские мифологические сказания (даже с прямой отсылкой «Шидэт хүүрийн хулиас» 'Из повести «Волшебный мертвец»' [Цэрэнсодном 1989: 79]), к тибетскому оригиналу, и даже рождение персонажа с бычьими рогами и длинным коровьим хвостом по имени Массанг в калмыцкой сказке происходит в Индии [Калмыцкие сказки 1962: 273-278].

Но при этом предполагаемое Д. Цэрэнсодномом происхождение названия Долоон бурхан от древнего названия Долоон бяруу [Цэрэнсодном 1989: 203] может быть связано с семантикой лексической основы, восходящей к значениям 'детеныш копытного от года до двух, олененок', а также 'самка оленя' и 'рожать (о животном)'.

Проанализированные материалы позволяли предположить возможность реконструкции представлений, соответствующих сюжету о смене дня и ночи и погоне за оленихой, укрывавшей солнце, тем более что «солярной теме смены дня и ночи» соответствует и мотив из второго типа сюжета о происхождении Большой Медведицы мотив борьбы белого и черного быков, в которых воплощаются Хормуста и Араха [Неклюдов 1994а: 391].

В свете рассмотренных в первой части мифологических сказаний о Большой Медведице рассмотрим другие представления, связанные с этим созвездием, в культуре калмыков и ойратов.

\section{Представления, связанные с Большой Медведицей, у ойратов и калмыков}

Обряды, направленные на преодоление зимнего (темного) времени

В культуре калмыков, как и других монгольских народов, созвездие Большая Медведииа особо почитается и как отпускающее грехи. В народе бытует до настоящего времени примета, согласно которой все грехи будут отпущены, если произнести на одном дыхании семь раз следующий заговор: Долан одн, Долан бурхн, дола дәкч давтад келхла - килни уга 'Семь звезд, Семь бур- ханов, если повторить семь раз, то исчезнут грехи'.

В традиционной культуре калмыков считается, что грехи может отпустить покровитель народа Белый старец Цаһан аав (Цаһан авh), отпустить грехи просят и предков, представления о которых также связаны с почитанием Большой Медведицы у монгольских народов. «В шаманских гимнах Долоон эбуген - податель счастливой судьбы (ср. дзаягачи)» [Неклюдов 1994а: 391]. Л. Эрдэнэболд приводит сведения о распространенной среди ойратов Монголии песне «Огторгуйн Долоон бурхан» 'Семь божеств Вселенной', отмечая, что в этой популярной песне «семь божеств» соотносятся с матерью [Эрдэнэболд 2012: 27].

В культуре монголов и бурят Большая Медведица прежде всего именуется «Семью старцами» (монг. Долоон өвгөн, бур. Долон эбуген), и таковое толкование образов Семизвездицы может в какой-то мере быть связано с представлениями об отпущении грехов. В монгольских мифах персонажи, превратившиеся в семь звезд, представлены как мужчины, обладающие особыми способностями и одерживающие победу в состязаниях, и объяснение тому, почему их стали назвать «Семь старцев», следующее: «так давно это было, что стали они старцами». Однако и в заговорной формуле, и в языке калмыков чаще используются другие названия Большой Медведицы - Долан бурхн или Долан одн, то есть не акцентируется глубокий возраст (старость) персонажей.

Характеристика персонажей, превратившихся в звезды Большой Медведицы, как в прошлом воров, также не соответствует аспекту почитания созвездия как отпускающего грехи. В этой связи обратим внимание на образ Цаһан авһ 'Белый дядюшка' (также называемого Цаһан аав 'Белый дед, отец’) - персонажа калмыцкой мифологии, представляющегося в качестве старика, подателя счастливой судьбы (подобно Большой Медведице в монгольских шаманских гимнах) и также связанного с представлениями о потеплении (в образе хозяина года он совершает кочевку в день зимнего солнцестояния), как и Большая Медведица, которая способствует, согласно монгольским мифологическим сюжетам, общему потеплению за счет того, что была украдена одна звезда у Плеяд. Вза- 
имосвязь божества и созвездия в народной традиции не однозначна, но явна. Особенно она прослеживается в семантике смены темного и светлого времени, в связи с солярной темой. В народной культуре эта взаимосвязь божества и созвездия отражена даже в том, что у постамента памятника ${ }^{1}$ Белому старцу в г. Элисте установлены ${ }^{2}$ две мраморные доски. Одна мраморная доска - с изображением солнца в виде глаза, двух солярных знаков и выгравированной надписью на старокалмыцком «ясном письме» Делкән эзн Цаһан аав ('Хозяин мира Белый старец'), вторая - с выгравированным изображением созвездия Большой Медведицы и надписью «Делкән Цаһан аав - һазрин эзн, делкән иуг әмд тоотын аврагч» 'Белый старец властелин мира, покровитель всего живого на земле'. Общей характеристикой Большой Медведицы и Белого старца является также то, что они, считается, оберегают отары от волков и способствуют увеличению численности скота.

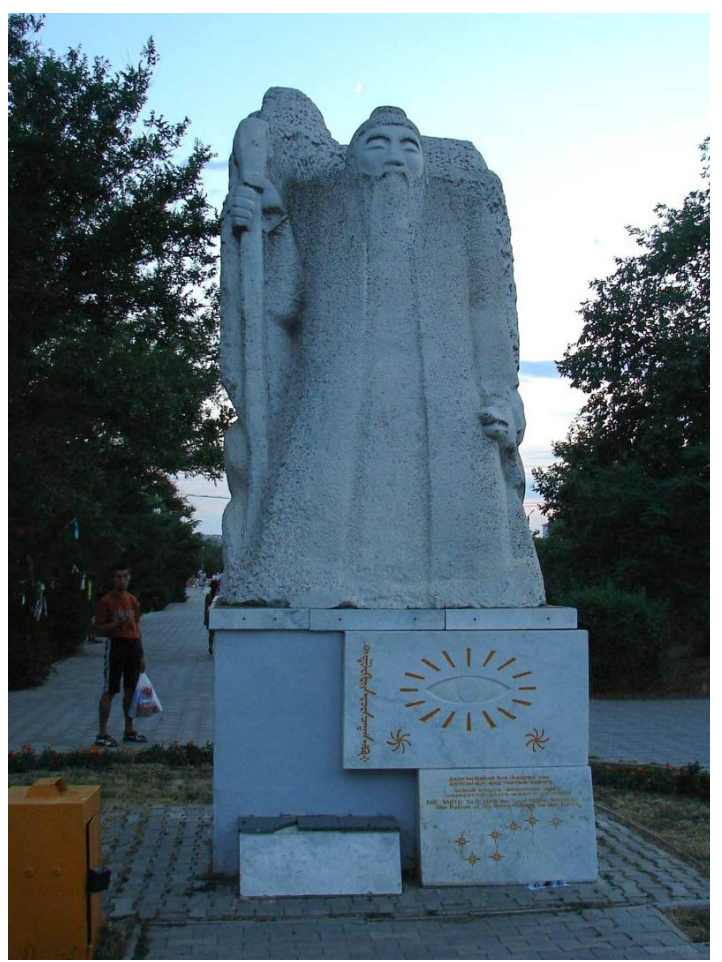

${ }^{1}$ Скульптор Н. Эледжиев. 1998 г.

${ }^{2}$ Примечательно, что статуя была установлена городской администрацией, а мраморная доска появилась по инициативе одного из религиозных объединений верующих мирян.

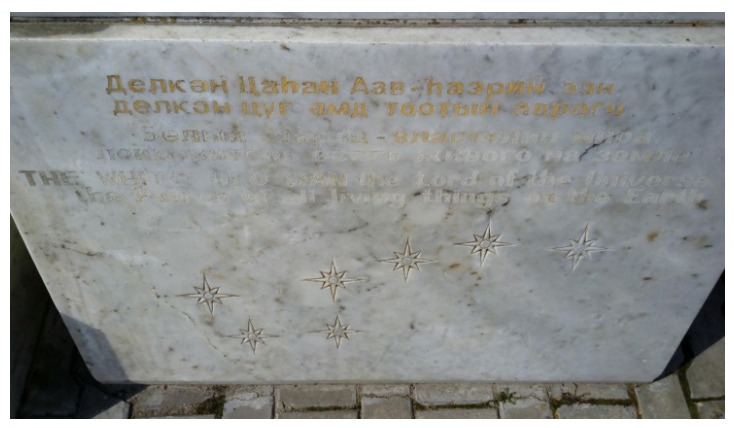

Puc. 1. Памятник Цаһан аав (Белому старцу) в г. Элисте.

У постамента - плита с изображением Большой Медведицы

[Fig. 1. Monument to the White Old Man (Kalm. Tsagan aav) in Elista.

The engraving beneath depicts Ursa Major]

Возможность перенесения на это созвездие отдельных функций и образа буддийского божества отмечалась исследователями в тувинской культуре, в которой, как известно, исследователями выявлялись общие черты с культурой соседних с ними ойратов [см., напр.: Трансграничная культура 2016]. Так, к числу предновогодних у тувинцев относились обряды почитания светил, в том числе обычай расположить перед наступлением новогодней ночи у порога или с внешней стороны над дверью юрты трех комочков снега величиной с кулак, «чтобы ими напоил своего коня бог Долаан (Большая Медведица), который якобы три раза обходил все аилы» [Монгуш 1992: 93].

При рассмотрении указанного мотива С. Ч. Донгак приводит эти данные М. В. Монгуш ${ }^{3}$ и пишет: «Созвездие Большой Медведицы здесь, как видно, названо богом (божеством). Можно полагать, что буддийский культ имел в данном случае местную интерпретацию, поскольку, по словам 3. Б. Самдан, в тувинском фольклоре не выявлен мотив или сюжет, в котором Долаан Бурган ездил бы на коне. Таким образом, культ Палден Лхамо 4 (Ламы Бурган) некоторыми тувинцами был перенесен на небесный объект» [Донгак 2015: 102].

${ }^{3}$ Ссылка дается на те же данные, но опубликованные ранее в статье: [Монгуш 1990: 3].

${ }^{4}$ С. Ч. Донгак основывается на том, что в преддверии наступления праздника Шагаа тувинцы ожидают появления божества Палден Лхамо, называемой Лама бурган (т. е. Лхамо бурхан). 
Однако здесь необходимо внести уточнение. Действительно, в культуре монгольских народов (в том числе ойратов) и тувинцев наступление Цаган сара (тув. Шагаa) связывается с образом Палден Лхамо (ойр., калм. Окн Тенцгр 'небесная дева'). Но в ойратской традиции в этот день поклоняются божеству Цаһан аав, а накануне Цаган сара, ожидая появления в мире людей Белого старца, снаружи справа над притолокой двери или на стыке дверного косяка и стены юрты помещают снег и лед (бытовая мотивация - «чтобы дорога была снежной»), а слева, чтобы не появился шулмус (ойр. шулам), втыкают колючую ветку караганы [Аюуш 2012: 89; Алтайн урианхайн 2014: 130]. Наши информанты-олёты также упоминали о традиции в этот день помещать над дверью снаружи кусочки льда [Бакаева 2016б: 183]. Учитывая наличие большого ряда общих культурных традиций у ойратов и тувинцев, можно провести сопоставление обычаев ойратов и сведений, приводимых М. В. Монгуш о тувинской традиции, которое дает основание сделать вывод о вероятности частичного наложения образов Цагаан аав и Долоон бурхан в народной культуре.

По данным М. В. Монгуш, моление созвездию Большой Медведицы (тув. Улуг Чеди хан; монг. Долоон бурхан, отсюда тувинское название Долаан бурган) у тувинцев проводилось 22-го числа каждого месяца почти в каждой семье. В честь созвездия в домах возжигали лампаду, приглашали ламу для совершения обряда умилостивительного характера. «Считалось, что одновременно с чтением молитв происходило „Угощение“ звезды. Этот ритуал, по мнению лам, оберегал семью от бед. Каждой звезде, как и всему созвездию, приписывалась способность влиять на судьбы людей, благополучие скота и хороший травостой» [Монгуш 1992: 93].

Здесь интересный момент связан с датой проведения молений: 22-е число (хотя и по лунно-солнечному календарю), символика которого, прежде всего, связана с датами солнцестояния в солнечном календаре (в монгольской же традиции дни почитания созвездия в каждом из лунных месяцев были различными).

Кроме того, отметим следующее. Тувинцы проводили обряд, направленный к Большой Медведице, заключавшийся в зажжении лампады и ее поднятии как можно выше на шесте, в преддверии нового года. М. В. Монгуш отмечает, что в ночь перед наступлением праздника Шагаа (калм. Цаһан сар) тувинцы совершали магические обряды, связанные с почитанием Большой Медведицы и Ориона (тув. Уч Мыйгак, монг. Гурван марал) [Монгуш 1992: 83]. При этом необходимо учитывать, что сам праздник в монгольской культуре был перенесен на начало весны [Жуковская 1985: 169-179; Жуковская 1988: 50], до этого начало нового года монгольские народы отмечали либо поздней осенью, либо ближе к зимнему солнцестоянию - у калмыков сохранилась вторая из этих древних традиций; бытование у тувинцев феноменологического календаря с отсчетом от зимнего солнцестояния [Потапов 1969: 293-296] также подтверждает бытование такой традиции в прошлом.

Подобные обряды, проводящиеся в один из дней первого зимнего месяца калмыками и в недавнем прошлом проводившиеся ойратами и монголами (на Монгольском Алтае), направлены к Белому старцу - хозяину пространства и покровителю (у калмыков и ойратов), время проведения обрядов связано с календарным циклом и днем солнцестояния. Речь идет о калмыцком обряде зажигания лампады с девятью фитилями (называемой йисн гол '9 фитилей') с поднятием ее на шесте сквозь дымоход кибитки в темное (звездное) время суток (в настоящее время - 25-го числа первого зимнего месяца, в прошлом - в дни солнцестояния, в пределах «старого» праздника нового года Жилин эзн). Символика обряда зажигания йисн гол заключается в преодолении зимнего (темного, холодного) периода: каждый из фитилей символически может быть приравнен к девятидневному периоду ${ }^{6}$

${ }^{5}$ В наши дни лампаду поднимают, прикрепив к длинной палке, как можно выше, находясь одной ногой в доме, другой - снаружи, что символически приравнивается к варианту проведения обряда в кибитке.

6 Параллелью этому обряду является обычай, зафиксированный в северном Китае, где закрашивали лепестки девяти нарисованных цветков, каждый день по одному лепестку из девяти на цветке, в течение 81 дня (подробнее: [Бакаева 2016а]). В наши дни древняя символика в калмыцкой культуре утрачена, и зажигание йисн гол считают просьбой о даровании счастья семье. 
(калмыки одновременно проводят и обряд продления лет жизни насан уттулх $x^{7}$ ).

В этот же день, причем поздним вечером, ойраты и халха-монголы, проживавшие на Алтае, по свидетельству М. Ганболда, еще в начале XX в. проводили обряд зажигания лампад, осмыслявшийся как направленный «на благополучное переживание зимнего и весеннего периодов» [Ганболд 2006: 114].

Символически значимым является зажигание лампад во время, когда на небе видны все звезды, на юрте, с закрытием лампад ледяным колпаком, приготовленным в посуде для доения (воду замораживали не до конца и вынимали получившуюся «ледяную емкость»). Захчины при этом ставили такое количество лампад, сколько членов семьи, плюс по количеству собак и по одной на породу скота, а халха-монголы устанавливали одну большую лампаду. М. Ганболд со слов информантов описал представления о том, что считалось: чем больше света от лампад, тем быстрее наступит теплое время года [Ганболд 2006]. Вместе с тем количество лампад по числу членов семьи свидетельствует о том, что обряд имеет отношение к продлению лет каждому члену семьи, т. е. обращено и к «подателю судьбы».

Таким образом, калмыцкий и ойратский обряды, несмотря на отличие в деталях, едины в семантике. Но калмыки еще сохраняют память о том, что обычай зажигания лампад имеет отношение к дню зимнего солнцестояния (день кочевки Хозяина года Жилин эзн, образ которого един с образом Цаһан аав, которого только калмыки, напомним, именуют также Цаһан авһ) - 22 декабря (по лунному календарю эта дата сдвигалась). Как нами отмечалось ранее, «обычай, сохранившийся у ойратов Монголии, является рудиментом архаического ритуала встречи начала нового года и продления лет, который в схожих формах и с сохранением мотивации бытует у калмыков. <..> В этой связи необходимо признать также, что обряды, проводимые 25 числа первого зимнего месяца, в день буддийского праздника лампад Зул, проводились, вероятно, и предками ойратов Монголии в день зимнего солнцестояния и имели символику прибавления силы солн-

7 Обряд заключается в зажигании одной большой лампады-лодочки с числом фитилей по количеству членов семьи и количеством травинок в каждом из фитилей по числу лет человеку плюс дополнительно одна-две. цу. Об этом свидетельствует уникальный по мифоритуальной форме обычай установки ледяного колпака над лампадой, которая растопит лед, как бы символизируя таянье застывшего на зиму небесного свода. В целом символика „прибавления силы солнцу“ отражена в обрядах и приготовлении в этот день обрядовой еды, связанной с символикой таяния. Так, 25 числа первого зимнего месяца в праздник Зул, как и в день Цагаан сар, монгольские ойраты обязательно гото-

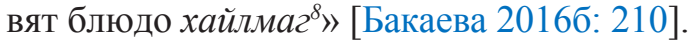

Бытующий у калмыков до настоящего времени обычай зажигания йисн гол позволяет предположить обрядовую связь с символикой растапливания ледяного колпака зимнего небосвода и увеличения силы солнца, завершения холодного зимнего периода. Символика девяти фитилей явно связана с системой счета зимнего времени со дня зимнего солнцестояния по девяти девятидневкам, который бытовал у ойратов, калмыков и тувинцев ${ }^{9}$ [Бакаева 2016а; Потапов 1969: 293-296].

Дата и время проведения обряда — темное время суток, в прошлом в день зимнего солнцестояния - вероятно, связаны с почитанием созвездий, которые в зимнем небе являются наиболее узнаваемыми, прежде всего с Большой Медведицей и Орионом, в которых наиболее заметными глазу являются семь звезд (с созвездием Ориона связано и почитание Сириуса).

Вместе с тем центральный персонаж, которому направлены моления обряда зажигания лампад - хозяин Алтая Цагаан $a a в$ (у ойратов) и Хозяин года, времени и пространства Жилин эзн ('Хозяин года'), он же Цаһан аав или Цаһан авһ (у калмыков). Образ Жилин эзн ${ }^{10}$ связан с солнцем, так как

${ }^{8}$ Хайлмаг - монг. «1. 1) кушанье из растопленной пенки; 2) плавка; 3) раствор; 2. 1) плавленный, расплавленный, растопленный; 2) растаявший; хайлмаг изас талый снег, растаявший снег» [БАМРС 2002: 19].

9 Тувинцы считали девятидневками также весь год, хотя, как и другие восточные народы, использовали и лунно-солнечный календарь [Потапов 1969: 293-296].

${ }^{10}$ В калмыцкой легенде о Цагин эзн 'Хозяине времени' он постоянно обходит белый свет, если он остановится, то время остановится, и все живые существа погибнут. Но на ночь он останавливается и ночует у своих тридцати жен попеременно [Мифы, легенды 2017: 52-53]. 
считается, что хозяин года кочует один раз в году - в дни зимнего солнцестояния - и наделяет годами жизни, т. е. является распорядителем судеб. В то же время проведение обрядового зажигания лампад «продления лет» и «девяти фитилей» в позднее ночное время свидетельствует и о связи этого действа с зимним и ночным периодом, завершение которого для древнего человека связано с представлениями о победе солнца над тьмой и о преодолении стужи (потеплении), т. е. о продолжении жизни.

Символика солнечного божества, предка, хозяина времени и пространства, характерная для образа Цаһан авһ в культуре калмыков, а также наличие традиции проведения обрядов, направленных ему, в ночное зимнее время (в день зимнего солнцестояния 22 декабря, который затем был заменен днем буддийского праздника огней), позволяет обратиться к анализу возможного соответствия обрядовой семантики типу архаического календаря, в котором два сезона связывались с образами копытного и медведя и соответственно с мифом о погоне за копытным, укравшим солнце: подобный тип сезонного календаря характерен для ряда народов таежной зоны северной Евразии, у которых длительный зимний период маркировался образом оленя (лося), а короткий летний период - образом медведя, хотя характерной была и смена символов: у одних народов выход медведя из берлоги означал начало лета, а начало гона у оленя - начало осени и охоты на них, у других народов зимняя спячка медведя ассоциировалась с темным периодом, а отел оленей - с летним ${ }^{11}$ [Лушникова 2006; Бакаева 2011: 10].

Предки калмыков - ойраты, как и ряд других народов, относились к так называемым «лесным» народам, обитавшим в таежной зоне. Потому в их культуре зафиксированы сведения о древнем календаре охотничьего типа. До XVII в. среди калмыков, переселившихся в пределы России, сохранялся народный календарь, отражавший специфи-

${ }^{11}$ Как показывает А. В. Лушникова, «оппозиция зооморфных персонажей различается по ареалам: для лесотаежной зоны она представлена парой „медведь - лось“, для равнинной (степной, тундровой) - парой „волк - олень“. Оппозиция „медведь - лось“ особо значима в мировоззрении таежных охотников» [Лушникова 2006: 30]. ку этнической культуры разных ойратских групп, ставших основой калмыцкого этноса. Благодаря книге Н. Витсена, работавшего в России в XVII в., остались зафиксированными названия месяцев календаря, восходящего к охотничьему типу, бытовавшего среди калмыков во время его пребывания в России [Witsen 1785; Бакаева 2007].

Календарь, сведения о котором зафиксировал Н. Витсен со слов калмыков в 1660-х гг. ${ }^{12}$, представлял собой систему счета времени, характерную для раннего периода этнической истории ойратов. Он типологически схож с календарем охотников тайги, в котором прослеживалась ориентация на движение луны и солнца (см. подробнее: [Бакаева 2007; Бакаева 2011]).

В целом годичный календарь имел сходство с бытовавшими в более поздние времена народными календарями бурят и монголов, но и отличался спецификой, заключавшейся прежде всего в разном соответствии сезонам, «сдвижке» аналогичных названий месяцев. Названия месяцев связаны с ранним периодом этнической истории ойратов, временем, когда основные занятия их предков были связаны с охотой, так как основные значения терминов определяют круг животных и птиц, дележа долей и др.

На основании анализа сведений о раннем календаре, сохранявшемся у калмыков в XVII в., а также особенностей календарных обрядов можно сделать вывод, что «у этнических предков калмыков в прошлом существовал древний сезонный календарь, в котором маркерами двух основных сезонов являлись образы медведя и оленя, связанные с периодами зимы и лета. Лексические и этнографические данные дают основание для вывода о взаимозаменяемости образов этих двух животных для обозначения теплого и холодного периодов» [Бакаева 2011: 12]. Этот вывод может быть подкреплен возможной интерпретацией слова $\mathrm{Caza}^{13}$

${ }^{12}$ Н. Витсен на протяжении полутора лет находился в России (в 1664-1665 гг.) в составе голландского посольства под руководством Якоба Борейля и позднее также посещал страну.

${ }^{13}$ Хотя считается, что название «Сага» связано с тибетским влиянием: название Сага дава ('месяц Сага'), относящееся к празднику в первом летнем месяце по лунно-солнечному календарю, характерно и для тибетской культуры; при этом сага означает название созвездия: «saga viśakhā, rādha назв. созвездия» [Рерих 1987: 13]. 
(название календарной даты, маркирующей начало лета у калмыков до XIX в.) как формы слова coha 'самка оленя, оленуха' 14 [КРС 1977: 453], а также вероятной этимологией названия месяца көкг (монг. хөхөө ${ }^{15}$; в калмыцком календаре, зафиксированном Н. Витсеном, это месяц зимнего солнцестояния) от тюркского названия медведя кок [Серошевский 1993: 634, 631] ${ }^{16}$. Тем более что в мифах об освобождении солнца образ охотника у разных монгольских народов может быть связан с медведем или богатырем Хухэдэй (Кокодо, Кокодей) Мэргэном, в имени которого прослеживается тот же корень кок (монг. хөх) [Бакаева 2009: 39].

В Древнетюркском словаре слово кӧк имеет несколько значений, среди которых первым является 'небо' [ДТС 1969: 312]. Соответственно слово кӧкdäki имеет значение 'находящийся на небе' [ДТС 1969: 313] (ср. имя небесного охотника в мифах монгольских народов - Хөхдэй или Хухэдэй). Обратим внимание на название месяца зимнего солнцестояния в архаичном календаре предков калмыков (ойратов) көкг, соответствующее монгольскому термину хөхөө, одно из значений которого «морозная погода, трескучие морозы» [БАМРС 2002: 150].

Согласно известному мифу небесный охотник (или медведь в самых ранних версиях) за оленем/оленями освобождает солнце, время действия - темный холодный пе-

${ }^{14} \mathrm{Cp}$. бурятское название Большой Медведицы Долоон согоо, о котором упоминает Д. Цэрэнсодном [Цэрэнсодном 1989: 202]. В этимологическом словаре тюркских языков также приводится слово со:вак, обозначающее 'вид антилопы, косуля, олень’ [ЭСТЯ 2003: 295] и предположительно связанное с уйгурским soy-a 'рог антилопы' и соответствующим sоyu $\gamma$-a [ЭСТЯ 2003: 295].

15 Термин хөхөө, согласно академическому монгольско-русскому словарю, имеет два значения: I. «Кукушка», II. Хөхөө өвөл - «самое холодное время зимой, сильные трескучие морозы» [БАМРС 2002: 150].

16 В историографии имели место попытки связать этимологию названия самого холодного зимнего месяца со значением хөхөө өвөл, где $x ө x$, по мнению Ж. Цолоо, означает синюю морозную дымку в разгар холодов [Цолоо 1994: 35-36]. В другом случае, когда месяц хөхөө в монгольском календаре выпадает на май, его название связывают с «началом периода кукования» кукушки. риод [Дашиева 2001]. Имя этого небесного охотника в мифах монгольских народов Хухэдэй (Кокодей) Мэргэн. Соответственно, в его имени прослеживается слово, обозначающее и синее небо, и зимнюю стужу (зимний, или темный, период), а в зафиксированном у якутов названии медведя термином «кок» можно видеть связь образа с представлениями о небесных мифологических событиях.

В монгольской мифологии семь звезд Большой Медведицы представляются и как стерегущие ночью двух соловых коней (монг. хоёр шарга морин), которые привязаны к золотому колу (монг. Алтан гадас 'Полярная звезда'), соответственно эти два коня - две звезды Малой Медведицы ${ }^{17}$. Эти соловые кони считаются то конями персонажей, превратившихся в Большую Медведицу [Долон бурхан 2006а; Долон бурхан 2006б], то конями Хухэдэй Мэргэна ${ }^{18}$ (монг. Хөхдэй мэргэн) [Цэрэнсодном 1989: 73 (№ 27. Тэнгэрийн зам ба долоон бурхан од 'Небесный путь и Большая Медведица')] — небесного стрелка, который, по мнению исследователей, сменил мифологический облик медведя, освобождающего солнце в древнейшем мифе о первотворении [Дашиева 2001]: для мифов монголоязычных народов характерен антропоморфный образ охотника Хухэдэй (ойрат. Кокодей) Мэргэна. Таким образом, в этом случае может прослеживаться воз-

${ }^{17}$ В культуре тувинцев «Первые три хорошо видимые звезды из созвездия Малой Медведицы называют арканом (аргамчы), а остальные две - capbl-ammap, т. е. желтые (соловые) лошади, будто бы привязанные арканом к золотому колу и всегда держащиеся от него на одном и том же расстоянии, в любом положении созвездия на ночном небе» [Потапов 1969: 293]. Л. П. Потапов, приводя названия звезд и созвездий у тувинцев, отмечает, что они представляют материал «для сопоставления их с названиями соответствующих звезд и планет у других народов (особенно у соседних) и для рассмотрения родства, общности языка и культуры этих народов» [Потапов 1969: 293]. Как видно на примере представлений о звездах Малой Медведицы, в культуре тувинцев прослеживаются общие с монгольскими традиции.

${ }^{18}$ Г. Р. Галданова отмечала, что в бурятской культуре «иногда в роли конюших Небесного стрелка выступают Семь старцев..., которых впоследствии, видимо, стали называть Семь бурханов» [Галданова 1987: 20]. 
можная связь между Большой Медведицей и образом небесного стрелка, в имени которого сохраняется корень, восходящий к его зооморфному прообразу.

Такая связь прослеживается ясно в алтайском мифологическом сюжете о происхождении Большой Медведицы, содержащемся в героическом эпосе «Маадай-Кара». Когутей-мерген (алтайский вариант имени Хухэдэй Мэргэна) - сын богатыря Маадай Кара встречает шесть персонажей — шесть богатырей, обладающих необычными способностями, вместе они выполняют три испытания по приказу отца суженой Когутей-мергена, затем герой спасает свой народ от подземного владыки и все семеро превращаются в созвездие Семи ханов (Большую Медведицу), а невеста Когутей-мергена становится Полярной звездой [Маадай-кара 1973: 393; Тюхтенева 2013].

В мифологических сказаниях монголов и ойратов образ Хухэдэй Мэргэна связан с представлениями о созвездии Орион, но в текстах упоминается и Большая Медведица. Так, считается, что три маралухи, которых преследовал Хухэдэй Мэргэн, превратились в три звезды Пояса Ориона. Сам же Хухэдэй Мэргэн — в самую яркую звезду на зимнем небе ${ }^{19}$, т. е. Сириус, находящийся на одной линии от Пояса Ориона ближе к горизонту — что символизирует следование охотника за маралами. В вышеупомянутом мифе о небесном пути и Большой Медведице ${ }^{20}$ [Цэрэнсодном 1989: 73] говорится о том, что хан Хухэдэй Мэргэн был во главе многочисленных туменов ${ }^{21}$ людей, которые с войском и скотом совершили великое кочевье и добрались до верхнего мира. Хухэдэй Мэргэн стал преследовать трех маралух. С того времени на небе Гурван марльн гурван янзага нь эхийгээ дагаж давхиад хойноос нь Хөхдэй мэргэн Асар Басар хоёр нохойтойгоо хөөжс явдаг гэжс өвгөд, Хөхдэй мэргэн од, гурван марал

19 Хөхдэй мэргэн - Хамгийн их гэрэлтэй ашдын од, хөхдэй мэргэн (https://mongoltoli.mn/ search.php?ug_id $=113856 \&$ opt $=1 \&$ word $=$ XӨXДЭЙ) [Монгол толь]. ('Хөхдэй Мэргэн — самая яркая звезда, Хухэдэй Мэргэн').

${ }^{20}$ Текст записан Б. Ринченом в 1936 г. от информанта Дагийраза из этнической группы шарнууд [Цэрэнсодном 1989: 203] 272].

${ }^{21}$ Тумен - десять тысяч [БАМРС 2001, III од, гурван янзага од, Асар, Басар од заадаг 'Указывают [на небе] старцев (т. е. Большую Медведицу), звезду Хухэдэй Мэргэн (т. е. Сириус), три звезды - три маралухи, три звезды - три мараленка, следующие за маралухами, и две звезды - собаки Acap и Басар, — так как Хухэдэй Мэргэн преследовал со своими собаками Асаром и Басаром трех маралух со следовавшими за ними тремя оленятами'22 [Цэрэнсодном 1989: 73]. Здесь отметим следующее: хотя в процитированном тексте термин өвгөд 'старцы' использован без числительного долоон 'семь', что могло бы стать причиной отсутствия в переводе упоминания созвездия Долоон бурхан (Долоон өвгөн), но в следующем абзаце текста мифологического сказания прямо указывается на созвездие Большая Медведица: Тэр хоёр шаргыг долоон өвгөн сахин манаж, шөнө хоёр шаргыг дагаж, алтан гадсыг эргэж явдаг гэж хэлэлиядэг. Тэр долоон өвгөнийг бас долоон бурхан ч гэж хэлэлидэг ёс бий 'Говорят, что этих двух соловых коней Семь старцев (т. е. звезды Большой Медведицы) сторожат и, сопровождая ночью этих двух коней, двигаются вокруг Золотого кола (т. е. Полярной звезды). Есть обычай называть этих Семь старцев также Семью бурханами’ [Цэрэнсодном 1989: 73].

В мифологическом тексте «Хөхдэй мэргэн», записанном в сомоне Бөхмөрөн ${ }^{23}$ Убсунурского аймака от сказителя Цагаадайн Зодова, говорится о том, как вооруженный луком и стрелами Хухэдэй Мэргэн охотится за тремя маралухами на белом коне, сопровождаемый двумя собаками. Блистающую на вечернем небе звезду называют Хухэдэй Мэргэном, а иногда небесным белым охотником ('тэнгэрийн цагаан анчин ч гэж хэлдэг байна' [Цэрэнсодном 1989: 49]), три звезды Пояса Ориона - тремя маралухами.

В следующем варианте мифа на небо поднимаются в процессе охоты Хөхдэй Мэргэн, сопровождающие его собаки, три маралухи, за которыми он охотится. В варианте, записанном от кукунорских олетов в Китае, также три звезды - это три маралухи;

22 Здесь и далее перевод мой. - Э. Б.

${ }^{23}$ В сомоне Бөхмөрөн (Бухмурэн) подавляющее большинство населения составляют ойраты-дербеты. 
над этими звездами - две звезды, это два охотника (слева Бямба, справа - Басан), с одной стороны от «маралух» - звезды, в которые превратились собаки Хасар и Басар, с другой стороны от «маралух» - звезды, в которых превратились птицы Хардаг и Нисдэг [Цэрэнсодном 1989: 50. № 15].

В варианте бурятского мифологического сказания находящиеся в центре созвездия три звезды - это три маралухи, под ними находятся звезды - три собаки Хухэдэй Мэргэна, в звезду превратился и конь охотника. Самая яркая звезда красного цвета ${ }^{24}$ — это стрела Хухэдэй Мэргэна, которой он собирался поразить маралух, она красного цвета от их крови. Согласно этому мифу, после уничтожения людей мангасом остались лишь семь старцев, которые поднялись на высокую гору и которых спас посланный Эцэгэ Маланом Хухэдэй Мэргэн. От семи старцев затем пошли все люди [Цэрэнсодном 1989: 50- 51. № 16].

Согласно устной традиции хобуксарских торгутов ${ }^{25}$ (ойратов, потомков калмыков), созвездие Орион (Гурван марал) также произошло от трех маралов, которых поразил стрелой Доголон Мэргэн ('Хромой Мэргэн'), стрела которого видна с обеих сторон от маралов [Цэрэнсодном 1989: 51. № 17].

В этой связи отметим следующее. С одной стороны, монгольские народы обычно связывают с образами маралов (оленей) созвездие Орион, которое называют по трем звездам Пояса ${ }^{26}$ Ориона Гурвн марл ('Три маралухи'), с другой стороны, во время экспедиции в Западную Монголию нами записано от дербетов название Большой Медведицы Долан марл ('Семь маралух') наряду с названием Долан бурхн. Сходное название видим в упоминаемом Д. Цэрэн-

\footnotetext{
24 Звезда Бетельгейзе - самая яркая звезда в созвездии Ориона - имеет красный цвет.

25 Торгуты Хобуксара (Синьцзян-Уйгурский автономный район КНР, далее - СУАР КНР) являются потомками подвластных калмыцкого нойона Цебека Дорджи, откочевавших из Калмыцкого ханства в 1771 г. Группа хобуксарских торгутов Монголии состоит из выходцев из СУАР КНР.

${ }^{26}$ В созвездии Орион, названном по имени охотника из древнегреческой мифологии, семь ярких звезд, три из которых находятся в центре на одной линии (образуя пояс Ориона), две над ними, словно обозначая плечи Ориона, две — в его ногах.
}

содномом варианте Долоон хого (согоо) $)^{27}$ [Цэрэнсодном 1989: 202]. Возможно, эти названия связаны с реликтами архаических представлений. Об этом свидетельствует семантика названия Долоон бяруу (калм. Долан бүрү), в котором второе слово восходит к значениям 'детеныш копытного, теленок, олененок', а также 'самка оленя' и 'рожать (о животном)'. Сходные лексемы, связанные с калмыцкими терминами бүрүл, бүркә, бүрүщ и монгольским бүрхий, со значениями 'темный, неясный, сумрачный, неясный, еле видимый' [Санжеев, Орловская, Шевернина 2019: 125-126] также могут быть связаны с древнейшими мифологическими представлениями о смене дня и ночи, о погоне за оленихой и освобождении солнца (об этом мифе см. подробнее: [Дашиева 2001]).

Но существует также вероятность, что название двух созвездий маралами может быть связано со смешением в поздней народной традиции представлений о семи звездах (в Большой Медведице и в созвездии Орион) и представлений о звездах как маралухах - так как в одних мифологических текстах образы персонажей, превратившихся в звезды Большой Медведицы, представляются как привязавшие своих коней к золотому колу (Полярной звезде) ${ }^{28}$

${ }^{27}$ Согоо - самка изюбря, оленя, маралуха [БАМРС 2001, III: 105].

${ }^{28}$ В одном из вариантов текстов, опубликованных на сайте Центра типологии и семиотики фольклора РГГУ, двух коней - серебряно-солового коня Мөнгөн шарга и янтарно-солового коня Хуван шарга - привязывают к Золотому колу братья Алтан Минжин ('Золотой Минжин’) и Мөнгөн Минжин ('Серебряный Минжин') перед тем как с названными братьями превратиться в созвездие Большой Медведицы [Долон бурхан 2006а]. Во втором варианте, записанном от того же информанта и опубликованном на том же сайте, старший брат Алтан Минжин ('Золотой Минжин') имеет коня Үнэгэн шарга и собаку Acap, а младший брат Мөнгөн Минжсин ('Cеребряный Минжин') - коня Хурган шарга и собаку Басар; перед тем как превратиться вместе с названными братьями в семь звезд, они вбивают золотой кол, который становится Полярной звездой, и привязывают к нему своих коней [Долон бурхан 2006б] (имена собак совпадают с именами собак персонажей, превратившихся в звезды Большой Медведицы, в ойратском мифе [Цэрэнсодном 1989: 50. № 15]). 
[Долон бурхан 2006а; Долон бурхан 2006б], в других - как стерегущие соловых коней Хухэдэй Мэргэна, привязанных к золотому колу (Полярной звезде) [Цэрэнсодном 1989: 73].

В целом необходимо отметить, что рассмотренные выше обряды, направленные на обеспечение скорого и благополучного завершения зимнего/темного времени, связаны в народных представлениях ойратов и калмыков, а также тувинцев с почитанием особенно хорошо видимых в зимнее время созвездий и с образом Белого старца. Дни зимнего солнцестояния в культуре калмыков связаны с образом Хозяина времени (года) Жилин эзн - одной из манифестаций образа Белого старца Цаһан аав, к которому обращены обрядовые действия с лампадами во время праздника Зул ${ }^{29}$. Сопоставление же адресатов калмыцких и ойратских обрядов с зажиганием лампад (йисн гол), направленных на скорейшее завершение темного (зимнего) времени, и адресата тувинского предновогоднего обычая - Долаан бурга$н a$, показывает возможную связь между божеством Цаһан аав и созвездием Большой Медведицы, которые также считаются отпускающими грехи и охраняющими стада от волков.

Материалы по архаическому календарю калмыков и опыт реконструкции раннего календаря их предков, отражавшего деление на два сезона, позволяют обнаружить элементы, которые свидетельствуют о его связи с мифологическим сюжетом о космической охоте и смене времен года. Название в охотничьем календаре калмыков XVIII в. первого зимнего месяца (месяца зимнего солнцестояния) көкг, на наш взгляд, взаимосвязано не только со значением названия в монгольском языке хөхө «морозной зимы», но и, возможно, с образом медведя, который в типологически сходных сюжетах о космической охоте был сменен антропоморфным персонажем - в культуре монгольских народов известным как небесный стрелок Хухэдэй (Кокодей) Мэргэн. Кроме того, образы Хухэдэй Мэргэна и Семи старцев (Семи бурханов) присутствуют в

29 25-е число первого зимнего месяца по лунно-солнечному календарю. В прошлом эти обряды проводились в день зимнего солнцестояния — день кочевки Жилин эзн. разных вариациях мотива о двух звездах Малой Медведицы, ассоциируемых в одних мифологических текстах с конями небесного стрелка, в других - с конями персонажей, превратившихся в звезды Большой Медведицы.

Ю. Е. Березкин при характеристике сюжета космической охоты, распространенного «в северной Азии с прилегающими областями Монголии и восточного Казахстана», отмечает, что он представлен многими вариантами, причем выделяются традиции, в которых сюжет космической охоты отражен в подробном повествовании (среди народов с такой традицией - ряд тюркских народов южной Сибири: телеуты, алтайцы, тувинцы, шорцы, хакасы, чулымские тюрки, тофалары, а также хоринские и аларские буряты, халха-монголы) и традиции, в которых «номинация звездных объектов опирается на краткое описание соответствующего сюжета» (среди народов с такой традицией - монгольские дархаты, дербеты, кукунорские олеты, якуты) [Березкин 2017: 76-77].

Ко второй группе народов, в которых отмечены ойраты, можно отнести и калмыков, среди которых указанный сюжет сохранился в «свернутом» виде. Вариант сюжета космической охоты, согласно которому три копытных животных стали тремя звездами Пояса Ориона, а охотник находится поодаль от них, согласно Ю. Е. Березкину, распространен «почти исключительно» среди монголов и тюрков - у тарбагатайских казахов, киргизов, алтайцев, телеутов, теленгитов, шорцев, хакасов, тувинцев и тофаларов, а также у халха-монголов, ойратов (дербетов и кукунорских ойратов), бурят. За пределами этого довольно компактного ареала ",космическая охота“" представлена совершенно другими текстами, основанными на интерпретации не Ориона, а Большой Медведицы» [Березкин 2017: 92]. При этом отмечается: «Космоним „Три маралухи“ для обозначения Пояса Ориона есть у калмыков [Басаев 2004: 10]. Не вполне ясно, записан ли у них соответствующий нарратив, но у предков калмыков, как и у всех ойратов, таковой, несомненно, был» [Березкин 2017: 92]. Этот тезис подтверждается, во-первых, тем, что среди потомков откочевавших на восток калмыков - хобуксарских торгу- 
тов - такой нарратив зафиксирован ${ }^{30}$, хотя и в краткой форме [Цэрэнсодном 1989: 51. № 17]; во-вторых, тем, что ареал распространения сюжета космической охоты, основанный на интерпретации Пояса Ориона, согласно исследованиям ученого, коррелируется с представлениями о Большой Медведице как семи мужских персонажах [Березкин 2017: 177].

Выводы ученого соответствуют основным сюжетам, записанным среди калмыков. Однако рассмотренные материалы отражают бытование в среде калмыков (а также родственных им ойратов) и других сюжетов, восходящих к представлениям о связи Большой Медведицы и сюжета космической охоты, что само по себе является уникальным. Среди южносибирских народов только у хакасов записан сюжет о космической охоте, согласно которому звезды Большой Медведицы - это три братаохотника, две их собаки и две преследуемые маралухи [Березкин 2017: 106], однако это более поздний сюжет. Как следует из приведенных выше материалов, отдельные элементы, возможно, свидетельствующие о представлениях о Большой Медведице как связанной с сюжетом о космической охоте (принадлежность коней, привязанных к золотому колу, Семи бурханам; одинаковые имена собак, сопровождающих Долоон бурхан и Хөхдэй Мэргэна; наименование большой Медведицы «Долан марл»; возможная адресация обряда, проводившегося ночью в день зимнего солнцестояния, Большой Медведице), не изучены, необходимо их дальнейшее детальное исследование. Но довольно ясно прослеживается корреляция между почитанием калмыками созвездия и божества-покровителя народа и «хозяина времени», имеющего солярную природу. Кроме того, образ Семи бурханов (т. е. звезд Большой Медведицы) и образ Хухэдэй Мэргэна оказываются взаимозаменяемыми в вариациях мотива о двух звездах Малой Медведицы, ассоциируемых с конями либо небесного

30 Д. Цэрэнсодном пересказывает содержание мифологического сказания хобуксарских торгутов о происхождении звезд Ориона от трех маралух, за которыми охотился Доголон мэргэн ('Хромой Мэргэн'), стрела которого видна с обеих сторон от маралов [Цэрэнсодном 1989: 51. № 17]. стрелка, либо персонажей, превратившихся в звезды Большой Медведицы.

Б. А. Рыбаков показал на обширном материале, что замещение культа лося/оленя, связанного с почитанием богини-прародительницы, культом медведя в североевразийском регионе связано со становлением отцовского рода и появлением мужских божеств, и этот процесс отразился в замещении ранних названий Большой Медведицы более поздними, связанными с ипостасью мужского божества в виде медведя [Рыбаков 1974; Рыбаков 1979]. Впоследствии «зооморфные черты этого образа все более вытесняются антропоморфными» [Лушникова 2006: 38]. Изложенные выше материалы о почитании монгольскими народами Большой Медведицы необходимо исследовать с учетом этой исторической «ретроспективы», прослеженной на материалах других культур.

Почитание Большой Медведиџь у современных ойратов и монголов

Л. Эрдэнэболд, характеризуя почитание Большой Медведицы в культуре ойратов, отмечает распространенность ойратской песни «Семь божеств Вселенной», в которой, по мнению ученого, прослеживается «развитие культа звезд, в том числе культа созвездия Семи старцев» [Эрдэнэболд 2012: 27]: в песне упоминаются обряды почитания Большой Медведицы в форме посвящений желтоголовой овцы, а последние куплеты посвящены буддийским храмам. В сборниках песен ойратов опубликованы и другие песни, посвященные этому созвездию. Тексты содержат слова о почитании родителей, старшего поколения, предков. Так, в песне «Долаан одон», записанной от Г. Чимэда из Убсунурского аймака Монголии, поется: Огторгын долаан одон орой дээр минь мандана. Олон сайхан ах нар Орчлон дээрэ жиргалтай <..> Харангуу сөөг гийгүҮлэгсэн Огторгаан долаан одон. Хайртай $ү р$ сээн өсгөгсөн ээж аав хуюр л 'Семь звезд Вселенной светят надо мной. Прекрасные старшие в этом мире благоденствуют <..> Светящим темной ночью Семи звездам Вселенной [подобны] Дорогие взрастившие нас мать и отец' [Дөрвөд ардын дуу 2004: 16-17].

В монгольской традиции считается, что почитание созвездия Большая Медведица 
являлось настолько значимым, что во время церемонии объявления Чингис-хана «ханом всей Монголии» был проведен обряд, направленный к этому созвездию: «...во время церемонии вручения ему титула золотого рода семь человек из золотого рода, посадив его на черный войлок, совершали обряд $<\ldots>$. В этом ритуале с участием семи человек, которые вставали на черный или белый войлок, последние считались медиаторами и главными исполнителями обряда, олицетворяя Семь старцев» [Эрдэнэболд 2012: 28].

Весьма развитый культ созвездия, имеющий архаические истоки, продолжает бытовать и в наши дни. Буддизм, для которого характерна инкорпорация ранних верований и обрядов в культ этой религии, включил в свой культ и представления и обрядность, связанные с почитанием созвездия Большой Медведицы.

Почитание созвездия Семи бурханов у ойратов, как и у монголов, имеет разные формы: повседневную форму, которую исполняют практически все верующие, форму совершения обрядовых действий перед охотой, форму проведения буддийского обряда посвящения животных.

Посвящение животного (монг. сэтэрлэх [БАМРС 2001, III: 165], калм. сетрлх) проводилось монгольскими буддистами в знак почитания божества. По сведениям М. Ганболда, алтайские урянхайцы сохраняли обычай посвящения Большой Медведице желтоголовой овцы до 60-х гг. ХХ в. [Ганболд 2001: 29; Эрдэнэболд 2012: 29], причем Л. Эрдэнэболд уточняет, что западные монголы «считали, что Большая Медведица приносит счастье людям, особенно детям. Поэтому семьи, не имеющие детей или имеющие нежно любимых детей, посвящали ей овцу со звездочкой на лбу» [Эрдэнэболд 2012: 27]. И. Лхагвасурэн также приводит сведения о почитании Большой Медведицы (Долоон бурхан) как приносящей счастье и оберегающей детей, о посвящении созвездию животного (овцы) с отметиной («звездочкой») на лбу [Лхагвасурэн 2013: 145].

Обряд, направленный на почитание Большой Медведицы, предписывалось совершать перед охотой. Так, алтайские урянхайцы при появлении звезд на небе поднимали войлочное покрытие над дымником юрты и совершали воскурение у проема верхнего круга жилища. А направляясь на охоту, они делали привал недалеко от жилища, также зажигали воскурение, обращались с просьбой к Большой Медведице ниспослать удачу в охоте и совершали троекратные поклоны [Бадамхатан, Лхагвасүрэн 2012: 422; Ганболд 2001: 29; Эрдэнэболд 2012: 27]. И. Лхагвасурэн приводит описание поклонения алтайских урянхайцев Большой Медведице как приносящей удачу в охоте: «Для этого охотники с наступлением сумерек, когда на небе появлялось созвездие, делали остановку в пути. Разводили огонь и ставили $c a H^{31}$, опять же разжигая можжевельник. Затем самый старший из них, обращаясь к Большой Медведице, громким голосом произносил следующие слова: „Послушай меня, Большая медведица! Послушай меня, Мать-земля! Даруй мне самца сурка! Даруй мне самку сурка!“. Закончив произносить эти слова, он опускался на колени и трижды склонял голову до самой земли. Все остальные следовали его примеру. Затем все угощались тем, что привезли с собой» [Лхагвасурэн 2013: 145]. Примечательно, что этот же ученый приводит и сведения о схожем обряде, совершавшемся охотниками - алтайскими урянхайцами в честь хозяина Алтая (то есть Белого старца): «На охотничьей стоянке охотники обязательно совершали обряд чествования хозяина Большого Алтая <..> в полдень или вечером. Для этого охотники сначала варили на костре молочный чай и готовили „жертвенную тарелку“ с молочными продуктами - идээний дээж (жертвенная еда), которые предварительно брали в путь. Затем сжигали можжевельник на жертвеннике (сан). После такого приготовления самый старший среди них бросал в огонь кусок масла с тем, чтобы обрадовать „хозяина“ огня, брызгал молочным чаем в четыре стороны (хангай, дэлхий). Затем он три раза обходил вокруг костра, разбрасывая понемногу молочные продукты из жертвенной тарелки „хозяевам“ местности. Все эти действия он сопровождал громким возгласом „Хурай! Хурай!“‘ Наконец, встав на колени лицом к костру с южной стороны, произносил следующие слова: „Ай, помилуй нас щедрый Алтай! Пусть конь мой с грузом будет! Пусть ружье мое промаха не делает! Пусть будет дикий козел! Пусть

\footnotetext{
${ }^{31}$ Сан (монг.) - воскурение.
} 
будет дикий кабан! Пусть будет олень!“. После этого ритуала начиналась совместная трапеза» [Лхагвасурэн 2013: 28].

В современной Монголии, в том числе среди ойратов, бытуют также обряды почитания Большой Медведицы, совершаемые повседневно или в определенные дни. Так, поскольку созвездие почитается как охраняющее стада от волков, то скотоводы ежедневно совершают Семи бурханам кропление молочными продуктами. Кроме того, ежедневное кропление молочными продуктами имеет мотивацию, связанную с молодым поколением. В известной легенде о Большой Медведице говорится о пожилой женщине, ожидавшей сына с военных действий, которая, совершая поклонение созвездию, неточно выразила свое желание встретиться с сыном и к тому же сказала: «Никогда себя не вверяла Семи бурханам», после чего она увидела его, но погибшим. Легенда завершается словами о том, что нужно всегда выказывать уважение и почитание созвездию Семи бурханов, всегда молиться во благо всех живых существ, Харин өглөөний ургах наранд өөрийгөө даатгадаг байна 'Всегда молиться [букв. вверять себя восходу солнца], когда утром восходит солнце', поэтому необходимо на восходе всегда подносить предкам чай с молоком с пожеланиями всего самого доброго и хорошего своим детям. Бытующая среди монголов и ойратов легенда о почитании Большой Медведицы подтверждает тезис об аспекте почитания созвездия как предков, благоволящих потомству и охраняющих детей. Кроме того, она обозначает связь обрядов почитания созвездия с солярным культом - в этом плане необходимо напомнить о народной традиции калмыков, установивших у постамента Белому старцу изображение созвездия Большой Медведицы и солнечного светила.

По сведениям Л. Эрдэнэболда, у ойратов существовал обычай седьмого числа каждого лунного месяца проводить обряд кропления цацал, посвященный созвездию Большой Медведицы, которому придавалось особое значение в связи с тем, что считалось: после его совершения семьей под покровительство созвездия попадают дети [Эрдэнэболд 2012: 28-29].

Как отмечала Г. Р. Галданова, культу Большой Медведицы посвящены обрядо- вые тексты, которые подверглись буддийскому влиянию. В бурятской культуре известен такой рукописный обрядник, который датируют XIV в., содержание которого имеет «военно-охотничью направленность», в нем упоминаются 99 тенгриев и 77 слоев матери земли, «говорится о том, что жертвоприношение состоит из девяти свечей, девяти благовоний, белой овцы, архи, чая» [Галданова 1987: 21].

Кроме этих представлений, с распространением буддизма появились и представления о связи Большой Медведицы с астрологическими приметами. Каждая из семи звезд связывается с определенным годом рождения человека, потому каждый человек должен поклоняться своей звезде из созвездия Большой Медведицы [ПМА: С. Хульда]. Определены и дни почитания созвездия Долоон бурхан в каждом из лунных месяцев: в начале года, в первом весеннем месяце, совершают поклонение Большой Медведице - Семизвездице в 7-й день; в среднем весеннем месяце такое поклонение проводят уже на 4-й день, а в последнем весеннем месяце - на 2-й день. При наступлении лета в начальном лунном месяце поклоняются звездам Большой Медведицы 27-го числа, в среднем летнем месяце на 5-й день, в последнем летнем месяце - 23-го числа. В первом осеннем месяце приносят жертвы и молятся звездам Большой Медведицы в 20-й день, в среднем осеннем месяце такое поклонение происходит в 17-й день, а в последнем осеннем месяце - опять 20-го числа. В первом осеннем месяце приносят жертвы и молятся звездам Большой Медведицы на 11-й день, в среднем осеннем месяце - в день полнолуния, а в последнем осеннем месяце - 8-го числа [ПМА: С. Хульда].

Среди текстов, посвященных Большой Медведице, фольклористами записано зафиксированное от ламы Баянхутагийна Долгорсурэна заклинание-тарни этому созвездию: Санаасаа бавуу дүйлаа жсвдон хул [Долон бурхан 2008б]. Но в буддийской сутре для людей, родившихся в разные годы согласно 12-летнему животному циклу, предназначены разные мантры, так как они должны поклоняться разным звездам Большой Медведицы.

Буддийская сутра, посвященная созвездию Большой Медведицы - «Doluyan 
ebügen kemekü odun-u sudur ${ }^{32} \gg$ ' 'Сутра coзвездия Долоон эбуген', включена в состав канонического свода буддийской литературы - Ганджура. Так, согласно каталогу рукописного Ганджура ${ }^{33}$ первой половины XVII в., по мнению 3. К. Касьяненко, являвшегося «рабочим экземпляром, написанным, возможно, в процессе подготовки первой редакции Ганджура ${ }^{34 » ~[К а т а л о г ~ 1993: ~ 9], ~}$ в томе 103 раздела Eldeb ('Собрание сутр') имеется сочинение «Doloyan ebügen neretü odun sudur» 'Сутра созвездия, называемого Долоон эбуген’ [Каталог 1993: 259].

Академик Ц. Дамдинсурэн, заложивший основы фундаментальных исследований монгольской литературы, включил текст сутры из монгольского Ганджура в публикацию «Ста образцов монгольской литературы» (краткое название «Дзуун билиг») [Damdinsürüng 1959: 131-136].

Издание явилось значимым и для монгольской культуры. Так, в последующем фольклористы фиксировали знание текста сутры именно по изданию «Дзуун билиг» [Долон бурхан 2007д].

Сутра, посвященная созвездию Большая Медведииа, зафиксирована в каталогах известных хранилищ письменных памятников монгольских народов. В Каталоге монгольских рукописей и ксилографов Института востоковедения АН СССР, подготовленном А. Г. Сазыкиным [Сазыкин 1988], в подразделе «Культ Семизвездия» отмечены несколько рукописей: № $1224-$ С 190 (I, 60), инв. № 615 «Doloyan ebügen-e mal-i seterlekü. Tngri-yin sudur» 'Сутра Неба о посвящении животных созвездию Долоон эбуген'; № 1225 - Q 2677, инв. № 6037 «Doloyan ebügen nertü odun-u dalal $\gamma$-a abqu sudur oršibai; Doluyan ebüged-i takiqui-yin jang yosun-i inu eyin» 'Сутра о призывании счастья от созвездия Долоон эбуген; О совершении подношения созвездию Долоон эбуген' (рук., 3 л.); № 1226 - О 3358, инв. № 6718 «7 burqan-u qubilyan doloyan ebügen

${ }^{32}$ Известна как «Yitikan sudur» [Ligeti 1954] (Jetigan - созвездие Большая Медведица [ДТС 1969: 259]).

${ }^{33}$ Из собрания библиотеки Восточного факультета Санкт-Петербургского государственного университета.

34 3. К. Касьяненко также предполагала, что, возможно, рукопись была переписана для пользования в каком-либо монастыре [Каталог 1993: 9]. neretü odun-u takil $\gamma$-a-yin sudur oršibai» ' $\mathrm{Cy}$ тра о совершении подношения созвездию Долоон бурхан' (3 л.) [Сазыкин 1988: 225]. Кроме того, в подразделе «Культ тэнгриев» упоминается и текст № 2297 - Q 1412, инв. № 4772 «Yeren tengri-yin jayayabar bütügsen yeke doloyan ebügen odon-i emüne...»'До созвездия великих Долоон эбуген, сотворенного волею 90 тенгриев...' (4 л.) [Сазыкин 1988: 401]. В каталоге монгольских рукописей и ксилографов Института монголоведения, тибетологии и буддологии СО РАН зафиксирована рукопись на старомонгольском письме - № 440. «7 ebügen neretü odun-u sudur orsiba» 'Сутра о созвездии под названием Долоон эбуген' [Tsyrempilov 2006]. Рукопись на ойратском «ясном письме» «Dolōn őbgőn kemekü oduni sudur orošibo» («Долоон өвгөн хэмэх одны судар оршвой» - 'Сутра о созвездии Долоон өвгөн', 13 листов, каталожный номер № 545[81]) хранится в единственном экземпляре в научном архиве Института языка и литературы Академии наук Монголии [Gerelmaa 2005: 183].

В Калмыкии эта сутра на ойратском языке не зафиксирована [Орлова 2002]. В научном архиве КалмНЦ РАН в фонде 15 (фонд О. М. Дорджиева (Тугмюд-гавджи)) имеется «Сутра о созвездии „Семь старцев“, приумножающая срок жизни и заслуги)» на тибетском языке (тиб.: sMe bdun zhes ba'i s kar ma'i mdo tshe dang bsod nams spel ba bz hugso. Монг. Doluүan ebügen neretü odun-u sudur). Это ксилограф [НА КалмНЦ РАН. ФД-15. ОП. 1. Ед. хр. 49] ${ }^{35}$ и рукопись [НА КалмНЦ РАН. ФД-15. Оп. 1. Ед. хр. 379] ${ }^{36}$ на тибетском языке (рукопись в каталоге архива числится под названием «Сутра о звездах „Жизнь и добродетель“»).

Наличие тибетской и монгольской версий «Сутры Большой Медведицы» актуализирует вопрос о переводном или самостоятельном характере текстов. Д. Кара отмечал, что сутра Большой Медведицы была переведена сначала с китайского языка на монгольский, а затем на уйгурский и в 1337 г. на тибетский [Кара 1981: 57]. Об этом свидетельствует тибетский перевод, «который содержит среднемонгольское заглавие и перевод среднемонгольского и среднеуйгур-

35 В ксилографе 8 листов (полн.), размер $58 \times 13 \mathrm{~cm}$.

36 В рукописи 15 листов (полн.), размер $21,7 \times 8,8 \mathrm{~cm}$. 
ского колофонов. Монгольский текст Ганджура <..> заново переведен с тибетского» [Кара 1981: 57]. Л. Лигети отмечает, что эта сутра должна была быть особенно популярна в XIV в. ${ }^{37}$, дата, присутствующая в тибетском и монгольском тексте - 1328 г. - относится ко времени издания, а не перевода [Ligeti 1954: 398].

Столь ранний перевод (до 1328 г.) свидетельствует еще раз о популярности культа созвездия. В колофоне сутры содержится информация, разъясняющая вопрос о последовательности переводов. Так, в сутре из рукописного Ганджура из научной библиотеки Санкт-Петербургского государственного университета написано, что сутру составил один пандита из Индии, ученый Танг Сан перевел сутру на китайский язык; затем по пожеланию Гим ирши гонглу тай гуу шири тай гуу Арибуги (Gim irši gonglu dai quu širi dai quu Aribu $\gamma$-a) уйгур Брадирашири ${ }^{38}$ (Bradir-a širi) перевел сутру на монгольский язык и ее напечатали в количестве 2 тыс. экземпляров; Алин ди мурди шиду (Alin di murdi sidu) перевел ее на уйгурский язык, и этот вариант напечатали в количестве 1 тыс. экземпляров, затем сутру перевели на тибетский язык ${ }^{39}$ [Каталог 1993: 259].

37 "Ce sutra devait etre particulierement populaire au XIVe siècle" [Ligeti 1954: 397]. Это мнение основано на приводимых в тексте сутры сведениях о том, что печатались тысячи ее экземпляров.

38 Д. Кара дает пояснение: Праджняшри [Кара 1981: 57]

39 «...ene nom-i Enedkeg-ün oron-ača Enedkegün nigen bandida kiged: erdem-tü Tang San čang

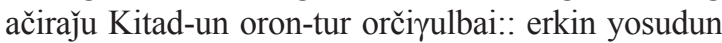

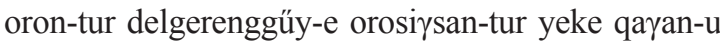
noyad tüsimed bodisung ijayur-dan tőrőged sűsűlküi bisireküi bilig kiged samadi diyan-tur tegülder bolbai: Gim irši gonglu dai quu širi dai quu Aribuy-a

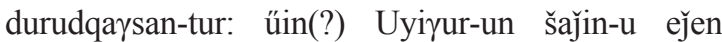
Bradir-a širi Mongyol-un kelen kiged üsüg-iyer

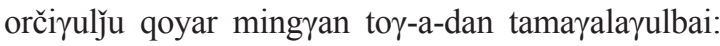

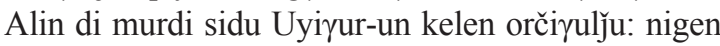

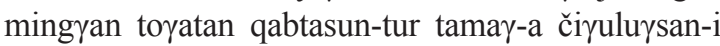
nom-un öglige bolyan tügegülbei: our Mongyol

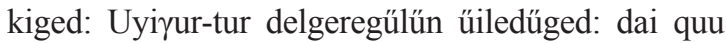
öber-iyen ber urida Mongyol-un nom-un törö-yi bariysan-tur: ene nim-un adistid-iyar burqan-u nomtur oroyad maysad yarču edünű erdem-üd-ün bisilyal-i tegsi amsabai: qoyina teng üker jil-tür Maq-a bala kelemeči kiged Širi ananda bašir-a:sa Güng tang-un süme-tür: Töbed-ün kelen kiged: tőbed üsüg-iyer

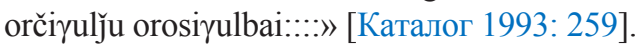

Книги раздавали в качестве подаяния [Каталог 1993: 259; Кара 1981: 57]. Необходимость ее перевода объясняется в сутре пожеланием, чтобы созвездие почитали все подданные монгольского государства, возможно, речь идет и о необходимости дать буддийское оформление древнему культу:

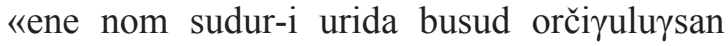
ügei bőgetele olan mongyol irgen bisirel-iyer takituyai: kemen our Mongyol-un kelen-iyer

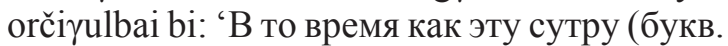
„религиозную книгу-сутру“) прежде другие не переводили, думая, пусть многочисленные монгольские поданные с благоговением почитают, на истинно монгольский язык перевел я’ [Каталог 1993: 259].

В наши дни основное содержание сутры (связанное с почитанием созвездия) популяризируют через интернет-сайты. Так, на сайте монгольской буддийской общины «Ламрим» размещены выдержки из текста сутры [Долоон бурхан одыг]. Но в этой публикации даются ошибочные сведения о том, с какого языка и на какой переводили сутру: в соответствии с распространенным мнением о том, что часто буддийские тексты переводили с уйгурского или тибетского языка, сообщается, что сутра Большой Медведицы была сначала «переведена с уйгурского на монгольский язык и опубликована в тысячах экземпляров. Китайский монах Тансан перевел ее на китайский и на тибетский язык и опубликовал их» [Долоон бурхан одыг]. В случае же с сутрой Большой Медведицы, как отмечал Д. Кара, уйгурский язык мог быть посредником между монгольским «оригиналом» (поскольку он был переведен с китайского) и тибетским переводом [Кара 1981: 58]. Отметим к тому же, что не все исследователи согласны вообще считать монгольскую сутру переводной. Так, по мнению исследователя из КНР Булага, «...не все буддийские сочинения на монгольском языке были переводными < .. > Значительная часть известной „Сутры Большой Медведицы“ является не переводом, а оригинальным монгольским сочинением; переводной является только ее первая часть» [Булаг 2001: 122].

Таким образом, сутра была переведена на монгольский язык уже на раннем этапе монгольского государства, что, возможно, было связано с популярностью культа созвездия. Несомненно, знакомству с ее текстом широких слоев населения способствовало печатание ксилографов тысячными ти- 
ражами. Но в каталогах хранилищ письменных памятников, описания которых были нам доступны, сутра Большой Медведицы зафиксирована в ограниченном количестве экземпляров. В XX в. благодаря изданию текста сутры (в широко известном «Дзуун билиг») и популяризации монахами (в том числе посредством интернет-ресурсов) среди монголов и ойратов Монголии сохраняются широко не только древние легенды о происхождении созвездия, но и представления, берущие начало в индийской астрологии и почитании отдельных звезд людьми, родившимися в разные годы по 12-летнему животному циклу.

Звезды в созвездии Большой Медведицы монголы и ойраты считают, как и другие народы, начиная от верхнего края «ковша»: крайняя звезда, «отмечающая» внешний край «ковша», именуется первой звездой, ей поклоняются люди, родившиеся в год мыши. Второй звездой считается звезда, «отмечающая» нижнюю часть внешней стороны «ковша»; ей должны поклоняться люди, родившиеся в год коровы или свиньи. Третья звезда - маркирующая внутренний нижний край «ковша» Большой Медведицы; ей должны поклоняться люди, родившиеся в годы тигра и собаки. Четвертая звезда та, которая отмечает край «ковша», с которого начинается его «ручка»; этой звезде должны поклоняться люди, родившиеся в годы зайца и курицы. Пятая звезда - та, что на условной схеме представляет собой начало «ручки» ковша; этой звезде поклоняются люди, родившиеся в годы дракона и обезьяны. Шестая звезда - находящаяся в самом «высоком» месте «ручки» «ковша» Семизвездицы; ей поклоняются родившиеся в годы овцы и змеи.

Таблииа 1. Соответствие годов рождения человека и звезды, которой он должен поклоняться

[Table 1. Stars to be worshipped by year of birth]

\begin{tabular}{|l|l|}
\hline 1 звезда & год Мыши \\
\hline 2 звезда & годы Свиньи и Коровы \\
\hline 3 звезда & годы Собаки и Тигра \\
\hline 4 звезда & годы Курицы и Зайца \\
\hline 5 звезда & годы Обезьяны и Дракона \\
\hline 6 звезда & годы Овцы и Змеи \\
\hline 7 звезда & год Лошади \\
\hline
\end{tabular}

Таблица 2. Годы двенадцатилетнего цикла и номера звезд, которым поклоняются люди, родившиеся в разные годы по этому циклу

[Table 2. Stars of the twelve-year cycle and ones to be worshipped by year of birth]

\begin{tabular}{|l|l|}
\hline Хлһн (мышь) & 1 \\
\hline Үр (корова) & 2 \\
\hline Бар (тигр) & 3 \\
\hline Туула (заяц) & 4 \\
\hline Лу (дракон) & 5 \\
\hline Моһа (змея) & 6 \\
\hline Мөрн (лошадь) & 7 \\
\hline Хөн (овца) & 6 \\
\hline Мөчн (обезьяна) & 5 \\
\hline Така (курица) & 4 \\
\hline Ноха (собака) & 3 \\
\hline Һаха (свинья) & 2 \\
\hline
\end{tabular}

Как видно, система выбора года, определяющего родившимся в этот год для поклонения звезду из Большой Медведицы, обусловлена принятой в монгольской традиции (как и в других традициях) нумера- цией звезд в созвездии - от альфа до этазвезд (см. рис. 2).

Согласно этой системе первой звезде соответствует и первый год в двенадцатилетнем цикле, второй звезде - вторые 


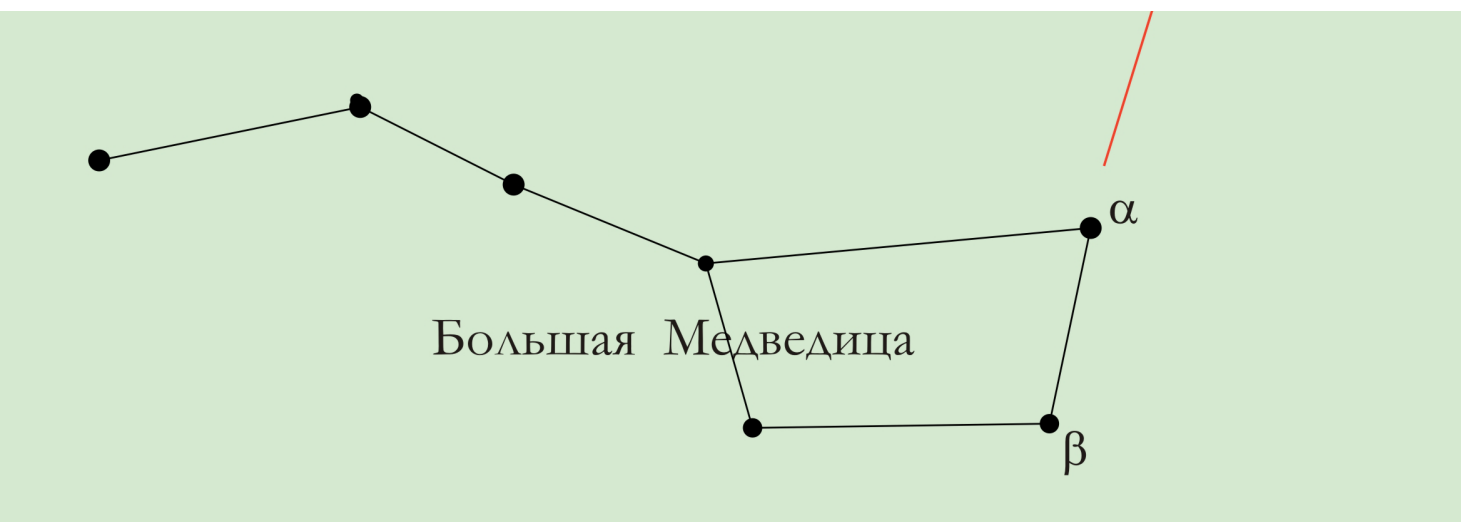

Puc.2. Счет звезд Большой Медведицы у монголов соответствует счету звезд от $\alpha$ и $\beta$

[Fig. 2. Mongolian count of URSA Major stars corresponds to the count of stars from $\alpha$ and $\beta$ ]

годы от начала и от конца в двенадцатилетнем цикле (что обеспечивает цикличность), третьей звезде - годы третьи от начала и конца в этом цикле, и так далее до седьмой звезды и седьмого года, находящегося в середине двенадцатилетнего цикла (символически это важно, так как обеспечивает возврат к началу и двулинейному отсчету годов рождения людей, не предполагающему наличие четкой границы, маркирующей конец).

\section{Заключение}

Проведенный анализ представлений, связанных с созвездием Большая Медведииа, позволяет выделить основные мифологические характеристики и осветить проблему разновременных напластований в верованиях о созвездии Большая Медведица в среде калмыков и ойратов (западных монголов). Следует отметить, что варианты мифологических сказаний о Большой Медведице, выявленные у ойратов, имеют сходство с основными вариантами мифа: о происхождении созвездия от семи мужских персонажей или от человеко-быка. В среде калмыков сохранились варианты мифов, которые в целом соответствуют двум типам сюжетов о Большой Медведице, распространенным в среде монгольских народов, но уникальным является сюжет о семи мужских персонажах как о семи ворах, характерный более для тюркских народов [Березкин 2017: 27], в сборнике монгольских текстов связь с темой воровства прослеживается только в одном из мифов, зафиксированных среди дербетов Монголии [Цэрэнсодном 1989: 202].
В устной традиции зафиксированы представления о том, что персонажи созвездия Большая Медведица, как и небесный охотник Хухэдэй Мэргэн (преследовавший трех маралух, которые обычно считаются превратившимися в три звезды Пояса Ориона и давшими название созвездию Орион монг. Гурван марал, калм. Һурвн марл 'Три маралухи'), могут считаться хозяевами двух привязанных к «золотому колу» (т. е. Полярной звезде) коней, в качестве которых предстают в мифах две звезды Малой Медведицы. Большую Медведицу калмыки почитают как связанную с потеплением на земле, а также покровительствующую детям, отпускающую грехи и защищающую отары от волков и способствующую увеличению численности скота - эти же функции характерны для божества Цаһан аав, одной из форм которого является Жилин эзн ('Хозяин года'). Таким образом, в целом прослеживается две линии связей представлений о Большой Медведице: с представлениями о небесном охотнике и о божестве Цаһан аав.

Сопоставительный анализ позволяет выявить и связь представлений о Большой Медведице с архаическими календарными обрядами, связанными с солярным культом и ритуалами, «воспроизводящими» акты первотворения. Разнородные элементы и образы, выявляющиеся в результате анализа представлений о созвездии, определены разновременными процессами и этнокультурными влияниями. В среде современных монгольских народов распространены представления о почитании созвездия Большая Медведица, связанные с буддийской астрологией и лунно-солнечным календарем. 


\section{Источники \\ НА КалмНЦ РАН - Научный архив КалмНЦ $\mathrm{PAH}$}

\section{Полевой материал автора ${ }^{40}$}

ПМА: М. Пагма - Мёнгкин Пагма, 1958 г. р., дөрвөд, седркә зуутраг овог, сомон Өлгий Убсунурского аймака Монголии. Запись 2015 г.

ПМА: С. Хульда - Сурэнгийн Хульда, 1933 г. р., торгут, бэйлэн, г. Кобдо Кобдоского аймака Монголии. Запись 2016 г.

\section{Литература}

Аюуш 2012 - Аюуш Ц. Дөрвөөд // Монгол улсын угсаатны зүй. II боть (= Дербеты // (= Этнография Монголии (Этнография ойратов) (XIX - начало XX в.). Часть II)). Улаанбаатар: Адмон ХХК, 2012. С. 27-106.

Алтайин урианхайн 2014 - Алтайн урианхайн угсаатны зүй (= Этнография алтайских урянхайцев) / ред. Г. Золбаяр, М. Ганболд. Улаанбаатар: «Китаб» ХХК, 2014.256 х.

Бадамхатан, Лхагвасүрэн 2012 - Бадамхатан С., Лхагвасүрэн И. Алтайн урианхай (= Алтайские урянхайцы) // Монгол улсын угсаатны зүй (Ойрадын угсаатны зүй) (XIXXX зууны зааг үе). II боть (= Этнография Монголии (Этнография ойратов) (XIX начало XX в.). Ч. II). Улаанбаатар: Адмон XXK, 2012. X. 361-424.

Бакаева 2007 - Бакаева Э. П. Данные Н. Витсена как источник по изучению раннего календаря (сравнительный анализ калмыцкого календаря и типологически сходных бурятского и монгольского календарей) // Востоковедные исследования в Калмыкии. Вып. 3. Элиста: Изд-во КГУ, 2007. С. 5-28.

Бакаева 2009 - Бакаева Э. П. Сакральные коды культуры калмыков. Элиста: ИКИАТ, 2009. $159 \mathrm{c}$.

Бакаева 2011 - Бакаева Э. П. К проблеме типологии культур народов севера Евразии (на примере календарной традиции калмыков) // Историко-культурное и межэтническое единство Юга России: мат-лы Всерос. науч.-практ. конф. (г. Астрахань, 8 октября 2011 г.) / сост. А. Р. Усманова, А. В. Сызранов. Астрахань: Издатель Сорокин Роман Васильевич, 2011. С. 6-13.

\footnotetext{
${ }^{40}$ Список информантов и список литературы
} приводятся в обеих частях статьи полностью.

\section{Sources}

Scientific Archive of the Kalmyk Scientific Center of the RAS

\section{Author's Field Data}

Informant: M. Pagma, b. 1958, Dorbet, Sedrkä Zuutrag clan, Ölgii District (Uvs Province, Mongolia). 2016.

Informant: S. Khulda, b. 1933, Torghut, Beylen clan, Khovd (Khovd Province, Mongolia). 2016 .

Бакаева 2016а - Бакаева Э. П. Об одной традиции монгольских народов // Этнографическое обозрение. 2016. № 6. С. 107-122.

Бакаева $2016 б$ - Бакаева Э. П. Образ божества Цаган аав (Белый старец) в культуре ойратов Монголии и калмыков России: предок, хозяин времени и пространства // Трансграничная культура: очерки сравнительно-сопоставительного исследования традиций западных монголов и калмыков / Э. П. Бакаева, К. В. Орлова, Д. Н. Музраева и др. Элиста: КалмНЦ РАН, 2016. С. 176-219.

Бакаева 2020 - Бакаева Э. П. Почитание Большой Медведицы в среде ойратов и калмыков: древнейшие представления и буддийские напластования. Часть $1 / /$ Oriental Studies. 2020. T. 13. № 2. C 368-384. DOI: 10.22162/2619-0990-2020-48-2-368-384

БАМРС 2001, I - Большой академический монгольско-русский словарь. Т. 1. А-Г / отв. ред. Г. Ц. Пюрбеев. М.: Academia, 2001. 520 с.

БАМРС 2001, II - Большой академический монгольско-русский словарь. Т. 2. Д-О / отв. ред. Г. Ц. Пюрбеев. М.: Academia, 2001. $536 \mathrm{c}$.

БАМРС 2001, III - Большой академический монгольско-русский словарь. Т. 3. Ө-Ф / отв. ред. Г. Ц. Пюрбеев. М.: Academia, 2001. $440 \mathrm{c}$.

БАМРС 2002 - Большой академический монгольско-русский словарь. Т. 4. Х-Я / отв. ред. Г. Ц. Пюрбеев. М.: Academia, 2002. $532 \mathrm{c}$.

Басаев 2008 - Басаев Д. Э. Космогонические легенды калмыков // Вестник Адыгейского государственного университета. Сер. 2: Филология и искусствоведение. 2008. № 6. С. $150-152$.

Басаев 2004 - Басаев Д. Э. Устная несказочная проза калмыков // Семь звезд. Калмыцкие легенды и предания / сост. Д. Э. Басаев. Элиста: Калм. кн. изд-во, 2004. С. 5-28. 
Березкин 2015a - Березкин Ю. Е. «Семеро братьев», «небесная повозка» и прародина индоевропейцев // Этнографическое обозрение. 2015. № 3. С. 3-1441.

Березкин 20156 - Березкин Ю. Е. Ответ оппонентам // Этнографическое обозрение. 2015. № 3. С. 26-40.

Березкин 2017 - Березкин Ю. Е. Рождение звездного неба: представления о ночных светилах в исторической динамике. СПб.: МАЭ РАН, 2017. 316 c. (Kunstkamera Petropolitana).

Булаг 2001 - Булаг. Религиозная литература монголов (пер. с монг. В. Л. Успенского) // Mongolica-V: Сб. ст. СПб.: Петербургское востоковедение, 2001. С. 119-123.

Васильков 2015 - Васильков Я. В. Большая Медведица, Плеяды и Алькор // Этнографическое обозрение. 2015. № 3. С. 14-18.

Галданова 1987 - Галданова Г. Р. Доламаистские верования бурят. Новосибирск: Наука, 1987. $116 \mathrm{c}$.

Ганболд 2001 - Ганболд М. Алтайн урианхайн уламжлалт шүтлэг (= Традиционные верования алтайских урянхайцев). Улаанбаатар: Соембо принтинг, 2001. 180 х.

Ганболд 2006 - Ганболд М. Обычай «зажигания лампады», или «зул барих» // Актуальные проблемы этнической, культурной и религиозной толерантности коренных народов Русского и Монгольского Алтая: мат-лы Междунар. науч. конф. (г. Горно-Алтайск, 23-24 ноября 2006 г.) / отв. ред. В. Г. Бабин. Горно-Алтайск: РИО ГАГУ, 2006. С. 111114.

Дашиева 2001 - Дашиева Н. Б. Календарь в традиционной культуре бурят (опыт историко-этнографического и культурно-генетического исследования). Улан-Удэ: Изд.-полигр. комплекс ВСГАКИ, 2001. 299 с.

Долон бурхан 2006а - Долон бурхан. Интервью с Ж. Цэндом (сомон Худжирт Убурхангайского аймака). Запись 20.08.2006 [электронный ресурс] // Мифо-ритуальные традиции Монголии. Тексты интервью 2006-2008 гг URL: https://www.ruthenia.ru/folklore/ mongexp.htm (дата обращения: 01.09.2016).

${ }^{41}$ Всего статья: С. 3-40 (комментарии: Васильков Я. В. Большая Медведица, Плеяды и Алькор; Дыбо А. В. Marginalia к статье Ю. Е. Березкина; Напольских В. В. К методам и основаниям сравнительно-исторических мифологических реконструкций) // Этнографическое обозрение 2015. № 3. С. 3-40 (основной текст статьи - С. 3-14, комментарии - С. 14-25, ответ оппонентам - С. 26-40).
Долон бурхан 20066 - Долон бурхан. Интервью с Ж. Цэндом (сомон Худжирт Убурхангайского аймака). Запись 21.08.2006 [электронный ресурс] // Мифо-ритуальные традиции Монголии. Тексты интервью 2006-2008 гг. URL: https://www.ruthenia.ru/folklore/ mongexp.htm (дата обращения: 01.09.2016).

Долон бурхан 2006в - Долон бурхан. Интервью с С. Дуламноргим (г. Арвайхээр, Убурхангайский аймак). Запись 24.08.2006 [электронный ресурс] // Мифо-ритуальные традиции Монголии. Тексты интервью 2006-2008 гг. URL: https://www.ruthenia. ru/folklore/mongexp.htm (дата обращения 01.09.2016).

Долон бурхан 2006г - Тэнгэрийн зам. Долон бурхан. Мичид. Луна. Интервью с Ж. Намжилом (сомон Ульдзийт Убурхангайского аймака). Запись 25.08.2006 [электронный ресурс] // Мифо-ритуальные традиции Монголии. Тексты интервью 2006-2008 гг. URL: https://www.ruthenia.ru/folklore/ mongexp.htm (дата обращения: 01.09.2016).

Долон бурхан 2007a - Долон бурхан. Интервью с 3. Хандсурэн (сомон Хатгал Хубсугульского аймака). Запись 22.08.2007 [электронный ресурс] // Мифо-ритуальные традиции Монголии. Тексты интервью 2006-2008 гг. URL: https://www.ruthenia.ru/folklore/mongexp.htm (дата обращения: 01.09.2016).

Долон бурхан 20076 - Долон бурхан. Интервью с Бат-Очиром (сомон Хатгал Хубсугульского аймака). Запись 23.08.2007 [электронный ресурс] // Мифо-ритуальные традиции Монголии. Тексты интервью 2006-2008 гг. URL: https://www.ruthenia.ru/folklore/mongexp.htm (дата обращения: 01.09.2016).

Долон бурхан 2007в - Долон бурхан. Интервью с Пурэвжавом (сомон Эрдэнэ-Булган Хубсугульского аймака). Запись 23.08.2007 [электронный ресурс] // Мифо-ритуальные традиции Монголии. Тексты интервью 2006-2008 гг. URL: https://www.ruthenia. ru/folklore/mongexp.htm (дата обращения: 01.09.2016).

Долон бурхан 2007г - Долон бурхан. Интервью с Л. Рагчаа (сомон Хатгал Хубсугульского аймака). Запись 23.08.2007 [электронный ресурс] // Мифо-ритуальные традиции Монголии. Тексты интервью 2006-2008 гг. URL: https://www.ruthenia.ru/folklore/mongexp.htm (дата обращения: 01.09.2016).

Долон бурхан 2007д - Долон бурхан. Интервью с Намдагийн Дагвадоржем (г. Булган, Булганский аймак). Запись 22.08.2007 [электронный ресурс] // Мифо-ритуальные 
традиции Монголии. Тексты интервью 2006-2008 гг. URL: https://www.ruthenia. ru/folklore/mongexp.htm (дата обращения: 01.09.2016).

Долон бурхан 2008а - Долон бурхан. Интервью с М. Шагдарсурэн и С. Батсухом (г. Ундурхан, Хэнтийский аймак). Запись 03.08.2008 [электронный ресурс] // Мифо-ритуальные традиции Монголии. Тексты интервью 2006-2008 гг. URL: https://www.ruthenia. ru/folklore/mongexp.htm (дата обращения: 01.09.2016).

Долон бурхан 20086 - Долон бурхан. Интервью с М. Шагдарсурэн и С. Батсухом (г. Ундурхан, Хэнтийский аймак). Запись 03.08.2008 [электронный ресурс] // Мифо-ритуальные традиции Монголии. Тексты интервью 2006-2008 гг. URL: https://www.ruthenia. ru/folklore/mongexp.htm (дата обращения: 01.09.2016).

Долоон бурхадын үлгэр 1 - Долоон бурхадын үлгэр (хувилбар-1). (Баярын «Ордосын аман үлгэр-ас». 1990 он) (= Сказание о Семи бурханах (версия 1) (из книги Баяра «Из народных сказаний ордосцев». 1990 г.)) [электронный ресурс] // URL: http://sokomongol. blogspot.com/p/blog-page_9072.html (дата обращения: 01.09.2019).

Долоон бурхадын үлгэр 2 - Долоон бурхадын үлгэр (хувилбар-2) (= Сказание о Семи бурханах (версия 2)) [электронный ресурс] // URL: http://sokomongol.blogspot.com/p/ blog-page_9072.html (дата обращения: 01.09.2019)

Долоон бурхан одыг - Долоон бурхан одыг тахих тухай (= О почитании созвездия Долоон бурхан) [электронный ресурс] // URL: https:/www.budda.mn/news/546.html (дата обращения: 01.07.2016).

Донгак 2015 - Донгак С. Ч. Вехи эволюции тувинского Шагаа // Новые исследования Тувы. 2015. № 1. С. 99-104.

Дөрвөд ардын дуу 2004 - Дөрвөд ардын дуу (=Дербетские народные песни). Улаанбаатар: Ганн принт ХХК, 2004. 180 х.

ДТС 1969 - Древнетюркский словарь. Л.: Наука, 1969. 677 с.

Дыбо 2015 - Дыбо А. В. Marginalia к статье Ю. Е. Березкина // Этнографическое обозрение. 2015. № 3. С. 18-22.

Жуковская 1985 - Жуковская Н. Л. Монголы // Календарные обычаи и обряды народов Восточной Азии. Новый год. М.: Наука; ГРВЛ, 1985. C. 169-189.
Жуковская 1988 - Жуковская Н. Л. Категории и символика традиционной культуры монголов. М.: Наука; ГРВЛ, 1988. 196 с.

Калмыцкие сказки 1962 - Калмыцкие сказки / сост. С. Д. Алексеев, Л. С. Сангаев. Элиста: Калмгосиздат, 1962. 332 с.

Кара 1981 - Кара Д. Уйгуро-монгольские литературные связи // Литературные связи Монголии. М.: Наука; ГРВЛ, 1981. С. 51-62.

Каталог 1993 - Каталог петербургского рукописного «Ганджура». Сост., введ., транслит. и указ. 3. К. Касьяненко. М.: Вост. лит., 1993. 380 с. (Памятники письменности Востока. CII. Bibliotheca Buddhica. XXXIX).

КРС 1977 - Калмыцко-русский словарь / под ред. Б. Д. Муниева. М.: Русский язык. 1977. $765 \mathrm{c}$.

Лушникова 2006 - Лушникова А. В. Модель Универсума древних календарей: на материале языков разных семей: автореф. дис. ... д-ра фил. наук. М., 2006. 55 с.

Лхагвасурэн 2013 - Лхагвасурэн Ичинхорлоо. Алтайские урянхайцы. Историко-этнографические очерки (конец XIX - начало XX в.) / пер. с монг. М. В. Монгуш. Улан-Удэ: Издво БНЦ СО РАН, 2013. 178 с.

Маадай-Кара 1973 - Маадай-Кара. Алтайский героический эпос. М.: Наука, 1973. 474 с.

Мифо-ритуальные 2006-2008 - Мифо-ритуальные традиции Монголии [электронный ресурс] // Тексты интервью 2006-2008 гг. URL: https://www.ruthenia.ru/folklore/mongexp.htm (дата обращения: 01.09.2016).

Мифы, легенды 2017 - Мифы, легенды и предания калмыков / подгот. текстов, пер., вступит, ст., примеч., коммент., указ., словарь, сверка калм. текстов Т. Г. Басанговой, Т. А. Михалевой; отв. ред. А. А. Бурыкин, Е. Н. Кузьмина, В. В. Куканова, Г. Ц. Пюрбеев; Калмыцкий научный центр РАН. М.: Наука - Вост. лит., 2017. 367 с.

Монгол толь - Монгол хэлний их тайлбар толь (= Большой толковый словарь монгольского языка) [электронный ресурс] // Монголь толь. URL: https://mongoltoli.mn (дата обращения: 10.09.2019).

Монгуш 1990 - Монгуи М. В. Свет далеких звезд // Тувинская правда. 1990. 24 ноября. C. 3.

Монгуш 1992 - Монгуш М. В. Ламаизм в Туве: Историко-этнографическое исследование. Кызыл: Тувин. кн. изд-во, 1992. 138 с.

Монгуш 2001 - Монгуш М. В. История буддизма в Туве (вторая половина VI - конец XX в.). Новосибирск: Наука, 2001. 200 с. 
Напольских 2015 - Напольских В. В. К методам и основаниям сравнительно-мифологических реконструкций // Этнографическое обозрение. 2015. № 3. С. 22-25.

Неклюдов 1994а - Неклюдов С. Ю. Долон эбуген // Мифы народов мира. Т. 1. М.: Советская энциклопедия, 1994. С. 391.

Неклюдов 19946 - Неклюдов С. Ю. Монгольских народов мифология // Мифы народов мира. Т. 2. М.: Советская энциклопедия, 1994. C. 170-174.

Неклюдов 1994в - Неклюдов С. Ю. Ойрат-калмыцкая мифология // Мифы народов мира. Т. 2. М.: Советская энциклопедия, 1982. C. 247-248.

Огнева 1994 - Огнева Е. Д. Масанг // Мифы народов мира. Т. 2. М: Советская энциклопедия, 1994. С. 122.

Орлова 2002 - Орлова К. В. Описание монгольских рукописей и ксилографов, хранящихся в фондах Калмыкии. Бюллетень Общества востоковедов. Вып. 5. М.: ИВ РАН, КИГИ PAH, 2002. $85 \mathrm{c}$.

Очиров 2006 - Очиров Н. О. Живая старина $=$ Мөңк дееж. Из литературного наследия / сост., вступ. ст., коммент. Б. А. Бичеева. Элиста: Калм. кн. изд-во, 2006. 397 с.

Потанин 1883 - Потанин Г. Н. Очерки Северо-Западной Монголии. Вып. IV. Материалы этнографические. СПб.: Тип. Киршбаума, $1883.181+87$ с., 26 рис.

Потапов 1969 - Потапов Л. П. Очерки народного быта тувинцев. М.: Наука; ГРВЛ, 1969. $402 \mathrm{c}$.

Рассадин 2015 - Рассадин В. И. Тюрко-монгольские названия крупного и мелкого рогатого скота в халха-монгольском языке // Вестник Калмыцкого института гуманитарных исследований РАН. 2015. № 3. C. 107-111.

Рерих 1987 - Рерих Ю. Н. Тибетско-русско-английский словарь с санскритскими параллелями / под общ. ред. Ю. Парфионовича и В. Дылыковой. Вып. 10. М.: Наука, 1987. $344 \mathrm{c}$.

Рыбаков 1974 - Рыбаков Б. А. Языческое мировоззрение русского средневековья // Вопросы истории. 1974. № 1. С. 3-30.

Рыбаков 1979 - Рыбаков Б. А. Космогоническая символика «чудских» шаманских бляшек и русских вышивок // Финно-угры и славяне. Л.: Наука, 1979. С. 7-34.

Сазыкин 1988 - Сазыкин А. Г. Каталог монгольских рукописей и ксилографов Института востоковедения Академии наук СССР
Т. І. Отв. ред. Д. Кара. М.: Наука. ГРВЛ, $1988.508 \mathrm{c}$

Санжеев, Орловская, Шевернина 2019 - Санжеев Г. Д., Орловская М. Н., Шевернина 3. В. Этимологический словарь монгольских языков. Т. І. А-Е. 2-е изд. М.: ИВ РАН, 2019. 224 c

Семь звезд 2004 - Семь звезд. Калмыцкие легенды и предания / сост., пер., вступ. ст., коммент. Д. Э. Басаева. Элиста: Калм. кн. изд-во, 2004. 415 с.

Серошевский 1993 - Серошевский В. Л. Якуты: опыт этнографического исследования. 2-е изд. М.: Ассоц. «Рос. полит. энцикл.», 1993. XVIII, 713 с., илл.

Трансграничная культура 2016 - Трансграничная культура: очерки сравнительно-сопоставительного исследования традиций западных монголов и калмыков / Э. П. Бакаева, К. В. Орлова, Д. Н. Музраева и др. Элиста: КалмНЦ РАН, 2016. 456 с.

Тюхтенева 2013 - Тулинова (Тюхтенева) С. П. Небесные Семь ханов - человеческие отцы или дети? [электронный ресурс] // Мат-лы IV Междунар. науч.-практ. конф. «Тенгрианство и эпическое наследие народов Евразии: истоки и современность» (г. Улан-Батор, 9-10 октября 2013 г.). URL: http:// tengrifund.ru/nebesnye-sem-xanov.html (дата обращения: 01.06.2019).

Цолоо 1994 - Цолоо Ж. Термины традиционного летосчисления у монголов // Этнокультурная лексика монгольских языков. Улан-Удэ: Изд-во БНЦ РАН, 1994. С. 27-43.

Цэрэнсодном 1989 - Д. Цэрэнсодном. Монгол ардын домог үлгэр (= Монгольские народные мифы и легенды). Улаанбаатар: Улсын хэвлэлийн газар, 1989. 240 х.

ЭСТЯ 1978 - Севортян Э. В. Этимологический словарь тюркских языков. Т. II. М.: Наука, $1978.349 \mathrm{c}$.

ЭСТЯ 2003 - Этимологический словарь тюркских языков. Общетюркские и межтюркские основы на буквы «Л», «М», «Н», «П», «С». М.: Вост. лит., 2003. 446 с.

Эрдэнэболд 2012 - Эрдэнэболд Лхагвасурэн. Традиционные верования ойрат-монголов (конец XIX - начало XX в.) / пер. на рус.: Ганбат Нямдаг, С. Б. Миягашева, Ж. Б. Бадагаров. Улан-Удэ: Изд-во БНЦ СО РАН, 2012. $196 \mathrm{c}$.

Gerelmaa 2005 - Gerelmaa G. Brief Catalogy of Oirat Manuscripts kept by Institute of Language and Literature (= Гэрэлмаа Г. Хэл зохиолын 
хурээлэнгийн тод үсгийн номын товч бүртгэл). Corpus Scriptorum Mongolorum Instituti Linguae et Litterarum Academiae Scientarum Republicae Populi Mongolici. T. XXVII. Fasc.1. Ulaanbaatar: Соёмбо Принтинг ХХК, 2005. $270 \mathrm{x}$.

Damdinsürüng 1959-Damdinsürüng Če. Mongyol uran jokiyal-un degeji jayun bilig orušibai // Corpus Scriptorum Mongolorum. T. XIV. Fasc. 2. Ulayanbayatur, 1959. 599 х. (= Дамдинсурэн Ц. Монгол уран зохиолын дээж зуун билиг оршибай = Сто образцов монгольской литературы). Улаанбаатар: Изд-во АН и Комитета по высшему образованию MHP, 1959. $599 \mathrm{x}$.

Ligeti 1954 - Ligeti L. Notes sur le colophon du "Yitikän sudur" // Asiatica. Leipzig: Otto Harrassowitz, 1954. P. 397-404.

Sazykin 1994 - Sazykin A. G. Catalogue of the

\section{References}

Alekseev S. D., Sangaev L. S. (comps.) Kalmyk Tales. Elista: Kalmgosizdat, 1962. 332 p. (In Kalm. and Russ.)

Ayuush Ts. The Dorbets. In: Ethnography of Mongolia. Vol. 2: Oirat Ethnography. Part 2: $19^{\text {th }}-$ Early $20^{\text {th }}$ Century. Ulaanbaatar: Admon, 2012. Pp. 27-106. (In Mong.)

Badamkhatan S., Lkhagvasüren I. The Altai Uriankhai. In: Ethnography of Mongolia. Vol. 2: Oirat Ethnography. Part 2: $19^{\text {th }}-$ Early $20^{\text {th }}$ Century. Ulaanbaatar: Admon, 2012. Pp. 361424. (In Mong.)

Bakaeva E. P. Image of Deity Tsagaan Aav (White Old Man) in cultural traditions of Mongoliabased Oirats and Russia-based Kalmyks: ancestor, master of time and space. In: Bakaeva E. P., Orlova K. V., Muzraeva D. N. et al. Cross-Border Culture. Comparative Studies in Western Mongolian and Kalmyk Traditions. Elista: Kalmyk Scientific Center of RAS, 2016. Pp. 176-219. (In Russ.)

Bakaeva E. P. N. Witsen's data as a source for the study of old calendars: a comparative analysis of the Kalmyk and typologically similar Buryat and Mongolian calendars. In: Oriental Studies in Kalmykia. Vol. 3. Elista: Kalmyk State University, 2007. Pp. 5-28. (In Russ.)

Bakaeva E. P. On a tradition of Mongolian peoples. Etnograficheskoe Obozrenie. 2016. No. 6. Pp. 107-122. (In Russ.)

Bakaeva E. P. Sacred Codes of Kalmyk Culture. Elista: Arid Territories Comprehensive Research Institute, 2009. 159 p. (In Russ.)

Bakaeva E. P. Typology of North Eurasian cultures revisited: a case study of the Kalmyk calendar
Mongol Manuscripts and Xilographs Preserved in the Library of the Tuvan Ethnological Museum "Sixty Heroes" (Kyzyl) // Acta Orientalia. Vol. 47. No. 3. Budapest: Akadémiae Kiadó, 1994. Pp. 327-408.

Tsyrempilov 2006 - Tsyrempilov N. Annotated Catalogue of the Collection of Mongolian Manuscripts and Xylographs M II of the Institute of Mongolian, Tibetan and Buddhist Studies of Siberian Branch of Russia Academy of Sciences. Sendai: Tohoku University, 2006 (CNEAS Monograph Series. Vol. 24). 413 p.

Witsen 1785 - Witsen $N$. Noord en Oost Tartaryen: behelzende eene beschryving van verscheidene Tartersche en nabuurige gewesten, in de Noorder en Oostelykste deelen van Azien en Europa. Amsterdam, M. Schalekamp, MDCCLXXXV (1785).

tradition. In: Usmanova A. R., Syzranov A. V. (comps.) South Russia - Historical, Cultural, and Interethnic Unity. Conf. proc. (Astrakhan; October 8, 2011). Astrakhan: R. V. Sorokin, 2011. Pp. 6-13. (In Russ.)

Bakaeva E. P. Veneration of Ursa Major among the Oirats and Kalmyks: Ancient Beliefs and Later Buddhist Additions. Part 1. Oriental Studies. 2020. Vol. 13. No. 2. Pp. 368-384. https://doi.org/10.22162/2619-0990-202048-2-368-384

Bakaeva E. P., Orlova K. V., Muzraeva D. N. et al. Cross-Border Culture: Comparative Studies in Western Mongolian and Kalmyk Traditions. Elista: Kalmyk Scientific Center of RAS, 2016. 456 p. (In Russ.)

Basaev D. E. (comp.) The Seven Stars. Kalmyk Legends and Stories. D. Basaev (foreword, etc.). Elista: Kalmyk Book Publ., 2004. 415 p. (In Russ.)

Basaev D. E. Kalmyk cosmogonic legends. The Bulletin of the Adyghe State University. Series 'Philology and Arts'. 2008. No. 6. Pp. 150-152. (In Russ.)

Basaev D. E. Kalmyk non-fairytale prose. In: Basaev D. E. (comp.) The Seven Stars. Kalmyk Legends and Stories. Elista: Kalmyk Book Publ., 2004. Pp. 5-28. (In Russ.)

Berezkin Yu. E. 'Seven brothers', 'sky wagon' and the Indo-European homeland. Etnograficheskoe Obozrenie. 2015. No. 3. Pp. 3-14. (In Russ.)

Berezkin Yu. E. Birth of Starry Heavens: Beliefs Dealing with Constellations in Historical Perspective. St. Petersburg: Peter the Great Museum of Anthropology and Ethnography (RAS), 2017. 316 p. (Ser.: Kunstkamera Petropolitana). (In Russ.) 
Berezkin Yu. E. Response to commenters. Etnograficheskoe Obozrenie. 2015. No. 3. Pp. 26-40. (In Russ.)

Bulag. Religious literature of Mongols (transl. by V. L. Uspensky). In: Kulganek I. V. (comp.) Mongolica-V. St. Petersburg: Peterburgskoe Vostokovedenie, 2001. Pp. 119-123. (In Russ.)

Burykin A. A., Kuzmina E. N., Kukanova V. V., Pyurbeev G. Ts. (eds.) Kalmyk Myths, Legends, and Stories. T. Basangova, T. Mikhaleva (transl., foreword, etc.). Kalmyk Scientific Center of RAS. Moscow: Nauka - Vostochnaya Literatura, 2017. 367 p. (In Kalm. and Russ.)

Damdinsuren Ts. Mongolian Literature: One Hundred Texts. Ser.: Corpus Scriptorum Mongolorum. Vol. XIV. Fasc. 2. Ulaanbaatar: Mongolian Academy of Sciences, 1959. 599 p. (In Mong.)

Dashieva N. B. Calendar in Traditional Buryat Culture: a Study in History, Ethnography, and Cultural Etymology. Ulan-Ude: East-Siberian State Academy of Culture and Arts, 2001. 299 p. (In Russ.)

Dolon Burkhan, Tengeriyn zam, Michid, and Moon: an interview with J. Namjil (Ölziit, Övörkhangai Province, Mongolia). Rec. on August 25, 2006. In: Mytho-Ritual Traditions of Mongolia. Interview Texts, 2006-2008. Available at: https://www.ruthenia.ru/folklore/ mongexp.htm (accessed: September 1, 2016). (In Mong.)

Dolon Burkhan: an interview with Bat-Ochir (Khatgal District, Khövsgöl Province, Mongolia). Rec. on August 23, 2007. In: MythoRitual Traditions of Mongolia. Interview Texts, 2006-2008. Available at: https://www.ruthenia. ru/folklore/mongexp.htm (accessed: September 1, 2016). (In Mong.)

Dolon Burkhan: an interview with L. Ragchaa (Khatgal District, Khövsgöl Province, Mongolia). Rec. on August 23, 2007. In: MythoRitual Traditions of Mongolia. Interview Texts, 2006-2008. Available at: https://www.ruthenia. ru/folklore/mongexp.htm (accessed: September 1, 2016). (In Mong.)

Dolon Burkhan: an interview with M. Shagdarsuren and S. Batsukh (Öndörkhaan, Khentii Province, Mongolia). Rec. on August 3, 2008. Part 1. In: Mytho-Ritual Traditions of Mongolia. Interview Texts, 2006-2008. Available at: https://www.ruthenia.ru/folklore/mongexp.htm (accessed: September 1, 2016). (In Mong.)

Dolon Burkhan: an interview with M. Shagdarsuren and S. Batsukh (Öndörkhaan, Khentii Province, Mongolia). Rec. on August 3, 2008. Part 2. In: Mytho-Ritual Traditions of Mongolia.
Interview Texts, 2006-2008. Available at: https://www.ruthenia.ru/folklore/mongexp.htm (accessed: September 1, 2016). (In Mong.)

Dolon Burkhan: an interview with N. Dagvadorzh (Bulgan, Bulgan Province, Mongolia). Rec. on August 22, 2007. In: Mytho-Ritual Traditions of Mongolia. Interview Texts, 2006-2008. Available at: https:/www.ruthenia.ru/folklore/ mongexp.htm (accessed: September 1, 2016). (In Mong.)

Dolon Burkhan: an interview with Purevjav (Erdenebulgan District, Khövsgöl Province, Mongolia). Rec. on August 23, 2007. In: MythoRitual Traditions of Mongolia. Interview Texts, 2006-2008. Available at: https://www.ruthenia. ru/folklore/mongexp.htm (accessed: September 1, 2016). (In Mong.)

Dolon Burkhan: an interview with S. Dulamnorgim (Arvaikheer, Övörkhangai Province, Mongolia). Rec. on August 24, 2006. In: MythoRitual Traditions of Mongolia. Interview Texts, 2006-2008. Available at: https://www. ruthenia.ru/folklore/mongexp.htm (accessed: September 1, 2016). (In Mong.)

Dolon Burkhan: an interview with Z. Khandsuren (Khatgal District, Khövsgöl Province, Mongolia). Rec. on August 22, 2007. In: MythoRitual Traditions of Mongolia. Interview Texts, 2006-2008. Available at: https://www.ruthenia. ru/folklore/mongexp.htm (accessed: September 1, 2016). (In Mong.)

Dolon Burkhan: an interview with Zh. Tsend (Khujirt District, Övörkhangai Province, Mongolia). Rec. on August 20, 2006. In: MythoRitual Traditions of Mongolia. Interview Texts, 2006-2008. Available at: https://www.ruthenia. ru/folklore/mongexp.htm (accessed: September 1, 2016). (In Mong.)

Dolon Burkhan: an interview with $\mathrm{Zh}$. Tsend (Khujirt District, Övörkhangai Province, Mongolia). Rec. on August 21, 2006. In: MythoRitual Traditions of Mongolia. Interview Texts, 2006-2008. Available at: https://www. ruthenia.ru/folklore/mongexp.htm (accessed: September 1, 2016). (In Mong.)

Dongak S. Ch. Milestones of evolution of Tuvan Shagaa. The New Research of Tuva. 2015. No. 1. Pp. 99-104. (In Russ.)

Dorbet Folk Songs. Ulaanbaatar: Gann Print, 2004. 180 p. (In Mong.)

Dybo A. V. Etymological Dictionary of Turkic Languages. Common and Inter-Turkic Stems Beginning with the Letters ' $L$ ', ' $M$ ', 'N', 'P', 'S'. Moscow: Vostochnaya Literatura, 2003. 446 p. (In Turk. and Russ.)

Dybo A. V. Marginalia on Yu. E. Berezkin's article. Etnograficheskoe Obozrenie. 2015. No. 3. Pp. 18-22. (In Russ.) 
Galdanova G. R. Buryat Pre-Lamaist Beliefs. Novosibirsk: Nauka, 1987. 116 p. (In Russ.)

Ganbold M. Oil lamp offering rite, or 'zul barikh'. In: Babin V. G. (ed.) Indigenous Peoples of the Russian and Mongolian Altai: Topical Issues of Ethnic, Cultural and Religious Tolerance. Conf. proc. (Gorno-Altaysk; November 23-24, 2006). Gorno-Altaysk: Gorno-Altaisk State University, 2006. Pp. 111-114. (In Russ.)

Ganbold M. The Altai Uriankhai: Traditional Beliefs. Ulaanbaatar: Soembo Printing, 2001. 180 p. (In Mong.)

Gerelmaa G. Brief Catalogue of Oirat Manuscripts Kept by Institute of Language and Literature. Corpus Scriptorum Mongolorum. Institute of Language and Literature, Mongolian Academy of Sciences. Vol. XXVII. Fasc.1. Ulaanbaatar: Soembo Printing, 2005. 270 p. (In Mong. and Eng.)

Kara D. Uighur-Mongolian literary ties. In: Literary Ties of Mongolia. Moscow: Nauka, 1981. Pp. 51-62. (In Russ.)

Kasyanenko Z. K. (comp.) Catalogue of the St. Petersburg Manuscript Kangyur. Z. Kasyanenko (foreword, translit., index). Moscow: Vostochnaya Literatura, 1993. 380 p. (In Russ. and Tib.)

Ligeti L. Yitikän sudur: notes to the colophon. In: Asiatica. Leipzig: Otto Harrassowitz, 1954. Pp. 397-404. (In Fr.)

Lkhagvasuren E. Traditional Beliefs of Oirat Mongols: Late $19^{\text {th }}-$ Early $20^{\text {th }}$ Centuries. G. Nyamdag, S. Miyagasheva, Zh. Badagarov (transl.). Ulan-Ude: Buryat Scientific Center (Sib. Branch) of RAS, 2012. 196 p. (In Russ.)

Lkhagvasuren I. The Altai Uriankhai: Historical and Ethnographic Essays, Late $19^{\text {th }}-$ Early $20^{\text {th }}$ Centuries. M. Mongush (transl.). Ulan-Ude: Buryat Scientific Center (Sib. Branch) of RAS, 2013. 178 p. (In Russ.)

Lushnikova A. V. Cosmological Model of Ancient Calendars: A Case Study of Languages Representing Different Language Families. Dr. Sc. (philology) thesis abstract. Moscow, 2006. 55 p. (In Russ.)

Maaday-Kara: A Heroic Epic of the Altaians. Moscow: Nauka, 1973. 474 p. (In Russ. and Alt.)

Mongush M. V. History of Buddhism in Tuva: Mid$6^{\text {th }}-$ Late $20^{\text {th }}$ Centuries. Novosibirsk: Nauka, 2001. 200 p. (In Russ.)

Mongush M. V. Lamaism in Tuva: A Historical and Ethnographic Review. Kyzyl: Tuvan Book Publ., 1992. 138 p. (In Russ.)
Mongush M. V. Light of remote stars. Tuvinskaya pravda. 1990, November 24. P. 3. (In Russ.)

Muniev B. D. (ed.) Kalmyk-Russian Dictionary. Moscow: Russkiy Yazyk, 1977. 765 p. (In Kalm. and Russ.)

Mytho-Ritual Traditions of Mongolia. Interview Texts, 2006-2008. Available at: https://www. ruthenia.ru/folklore/mongexp.htm (accessed: September 1, 2016). (In Mong.)

Nadelyaev V. M. et al. (eds.) Dictionary of Old Turkic. Leningrad: Nauka,1969. 677 p. (In Turk. and Russ.)

Napolskikh V. V. On methods and bases for comparative mythological reconstructions. Etnograficheskoe Obozrenie. 2015. No. 3. Pp. 22-25. (In Russ.)

Neklyudov S. Yu. Mythology of Mongolic peoples. In: Tokarev S. A., Braginsky I. S. (eds.) Myths of the World. Vol. 2. Moscow: Sovetskaya Entsiklopediya, 1994. Pp. 170-174. (In Russ.)

Neklyudov S. Yu. Oirat-Kalmyk mythology. In: Tokarev S. A. (ed.) Myths of the World. Vol. 2. Moscow: Sovetskaya Entsiklopediya, 1982. Pp. 247-248. (In Russ.)

Neklyudov S. Yu. The Seven Old Men. In: Tokarev S. A., Braginsky I. S. (eds.) Myths of the World. Vol. 1. Moscow: Sovetskaya Entsiklopediya, 1994. P. 391. (In Russ.)

Ochirov N. O. The Living Antiquity: Fragments of Literary Heritage. B. Bicheev (comp., foreword, etc.). Elista: Kalmyk Book Publ., 2006. 397 p. (In Kalm. and Russ.)

Ogneva E. D. Masang. In: Tokarev S. A., Braginsky I. S. (eds.) Myths of the World. Vol. 2. Moscow: Sovetskaya Entsiklopediya, 1994. P. 122. (In Russ.)

Orlova K. V. Description of Kalmykia-Based Mongolian Manuscripts and Xylographs. Ser.: Newsletter of the Russian Society of Orientalists. Vol. 5. Moscow: Institute of Oriental Studies (RAS), Kalmyk Humanities Research Institute of RAS, 2002. 85 p. (In Russ.)

Potanin G. N. Essays on Northwestern Mongolia. Vol. IV: Ethnographic Materials. St. Petersburg: Kirshbaum, 1883. 181+87 p. (In Russ.)

Potapov L. P. Tuvans: Sketches of Everyday Life. Moscow: Nauka; GRVL, 1969. 402 p. (In Russ.)

Pyurbeev G. Ts. (ed.) Unabridged Academic Mongolian-Russian Dictionary. In 4 vols. Vol. 1: A-Г. Moscow: Academia, 2001. 520 p. (In Mong. and Russ.)

Pyurbeev G. Ts. (ed.) Unabridged Academic Mongolian-Russian Dictionary. In 4 vols. 
Vol. 2: Д-O. Moscow: Academia, 2001. 536 p (In Mong. and Russ.)

Pyurbeev G. Ts. (ed.) Unabridged Academic Mongolian-Russian Dictionary. In 4 vols. Vol. 3: Ө-Ф. Moscow: Academia, 2001. 440 p. (In Mong. and Russ.)

Pyurbeev G. Ts. (ed.) Unabridged Academic Mongolian-Russian Dictionary. In 4 vols. Vol. 4: X-Я. Moscow: Academia, 2002. 532 p. (In Mong. and Russ.)

Rassadin V. I. Turkic-Mongolian names of neat and small cattle in the Khalkha Mongolian language. Bulletin of the Kalmyk Institute for Humanities of the RAS (Oriental Studies). 2015. No. 3. Pp. 107-111. (In Russ.)

Roerich Yu. N. Tibetan-Russian-English Dictionary with Sanskrit Parallels. Yu. Parfionovich, V. Dylykova (eds.). Vol. 10. Moscow: Nauka, 1987. 344 p. (In Tib., Russ., Eng., Sans.)

Rybakov B. A. 'Chud' shamanic pendants and Russian embroideries: cosmogonic symbols. In: Rybakov B. A. et al. (eds.) Finno-Ugrians and Slavs. Leningrad: Nauka, 1979. Pp. 7-34. (In Russ.)

Rybakov B. A. Russia in the Middle Ages: pagan worldview. Voprosy istorii. 1974. No. 1. Pp. 3-30. (In Russ.)

Sanzheev G. D., Orlovskaya M. N., Shevernina Z. V. Etymological Dictionary of Mongolic Languages. Vol. I: A-E. 2 $2^{\text {nd }}$ ed. Moscow: Institute of Oriental Studies (RAS), 2019. 224 p. (In Mong. and Russ.)

Sazykin A. G. Catalogue of the Mongol Manuscripts and Xylographs Preserved in the Library of the Tuvan Ethnological Museum 'Sixty Heroes' (Kyzyl). Acta Orientalia Academiae Scientiarum Hungaricae. 1994. Vol. 47. No. 3. Pp. 327-408. (In Eng.)

Sazykin A. G. Institute of Oriental Studies, USSR Academy of Sciences: Catalogue of Mongolian Manuscripts and Xylographs. Vol. I. Kara (ed.). Moscow: Nauka - GRVL, 1988. 508 p. (In Russ.)

Seroshevsky V. L. The Yakuts: An Ethnographic Study. $2^{\text {nd }}$ ed. Moscow: ROSSPEN, 1993. Vol. XVIII. 713 p. (In Russ.)

Sevortyan E. V. Etymological Dictionary of Turkic Languages. Vol. II. Moscow: Nauka, 1978. 349 p. (In Turk. and Russ.)

The Tale of the Seven Deities. Version One. In: Bayar. Folk Tales of Ordos Mongols. Available at: http://sokomongol.blogspot.com/p/blogpage_9072.html (accessed: September 1, 2019). (In Mong.)
The Tale of the Seven Deities. Version Two. Available at: http://sokomongol.blogspot. com/p/blog-page 9072.html (accessed: September 1, 2019). (In Mong.)

Tserensodnom D. Mongolian Folk Myths and Legends. Ulaanbaatar: People's Publ. House, 1989. 240 p. (In Mong.)

Tsoloo Zh. Traditional chronology of Mongols: terminology revisited. In: Ethnocultural Vocabulary of Mongolic Languages. UlanUde: Buryat Scientific Center (Sib. Branch) of RAS, 1994. Pp. 27-43. (In Russ.)

Tsyrempilov N. Annotated Catalogue of the Collection of Mongolian Manuscripts and Xylographs M II of the Institute of Mongolian, Tibetan and Buddhist Studies of Siberian Branch of Russia Academy of Sciences. Sendai: Tohoku University, 2006 (CNEAS Monograph Series. Vol. 24). 413 p. (In Eng.)

Tulinova (Tyukhteneva) S. P. The Seven Heavenly Khans - fathers or sons to humans? In: Tengrism and Epic Heritage of Eurasia Origins and Contemporaneity. Conf. proc. (Ulaanbaatar; October 9-10, 2013). Available at: http://tengrifund.ru/nebesnye-sem-xanov. html (accessed: June 1, 2019). (In Russ.)

Unabridged Explanatory Dictionary of the Mongolian Language. Available at: https:// mongoltoli.mn (accessed: September 10, 2019). (In Mong.)

Vasilkov Ya. V. Ursa Major, pleiades, and Alcor. Etnograficheskoe Obozrenie. 2015. No. 3. Pp. 14-18. (In Russ.)

Veneration of Ursa Major (Doloon Burkhan constellation): tradition revisited. Available at: https:// www.budda.mn/news/546.html (accessed: July 1, 2016). (In Mong.)

Witsen N. Noord en Oost Tartaryen: behelzende eene beschryving van verscheidene Tartersche en nabuurige gewesten, in de Noorder en Oostelykste deelen van Azien en Europa. Amsterdam, M. Schalekamp, MDCCLXXXV (1785). (In Dutch)

Zhukovskaya N. L. Mongolian Traditional Culture: Categories and Symbolism. Moscow: Nauka; GRVL, 1988. 196 p. (In Russ.)

Zhukovskaya N. L. Mongols. In: East Asian Peoples - Calendar Customs and Rites. New Year (Celebrations). Moscow: Nauka; GRVL, 1985. Pp. 169-189. (In Russ.)

Zolbayar G., Ganbold M. (eds.) Ethnography of the Altai Uriankhai. Ulaanbaatar: Kitab, 2014. 256 p. (In Mong.) 